\title{
Drifter observations of the Hebrides slope current and nearby circulation patterns
}

\author{
M. Burrows, S. A. Thorpe \\ Department of Oceanography, Southampton Oceanography Centre, European Way, Southampton, SO14 3ZH, UK
}

Received: 13 January 1998 / Revised: 18 June 1998 / Accepted: 23 June 1998

\begin{abstract}
The mean flow at and around the Hebrides and Shetland Shelf slope is measured with ARGOS tracked drifters. Forty-two drifters drogued at $50 \mathrm{~m}$ were deployed in three circles over the Hebrides slope at $56.15^{\circ} \mathrm{N}$ in two releases, one on 5th December, 1995 and the second on 5-9th May, 1996. The circles span a distance of some $20 \mathrm{~km}$ from water depths of $200 \mathrm{~m}$ to $1200 \mathrm{~m}$. Drifters are initially advected poleward alongslope by the Hebrides slope current at between 0.05 and $0.70 \mathrm{~m} \mathrm{~s}^{-1}$ in a laterally constrained $(25-50 \mathrm{~km}$ wide) jet-like flow. Drifters released in winter remained in the slope current for over $2000 \mathrm{~km}$ whilst summer drifters were lost from the slope current beyond the WyvilleThomson Ridge, a major topographic feature at $60^{\circ} \mathrm{N}$. Dispersion from the slope region into deeper waters occurs at bathymetric irregularities, particularly at the Anton Dohrn Seamount close to which the slope current is found to bifurcate, both in summer and winter, and at the Wyville-Thomson Ridge where drifters move into the Faeroe Shetland Channel. Dispersion onto the continental shelf occurs sporadically along the Hebrides slope. The initial dispersion around the Hebrides slope is remarkably sensitive to initial position, most of the drifters released in shallower water moving onto the shelf, whilst those in $1000 \mathrm{~m}$ or more are mostly carried away from the slope into deeper water near the Anton Dohrn Seamount. The dispersion coefficients estimated in directions parallel and normal to the local direction of the $500 \mathrm{~m}$ contour, approximately the position of the slope current core, are approximately $8.8 \times 10^{3} \mathrm{~m}^{2} \mathrm{~s}^{-1}$ and $0.36 \times 10^{3} \mathrm{~m}^{2} \mathrm{~s}^{-1}$, respectively, during winter, and $11.4 \times 10^{3} \mathrm{~m}^{2} \mathrm{~s}^{-1}$ and $0.36 \times 10^{3} \mathrm{~m}^{2} \mathrm{~s}^{-1}$, respectively, during summer. At the slope there is a minimum in across-slope mean velocity, Reynolds stress, and acrossslope eddy correlations. The mean across-slope velocity associated with mass flux is about $4 \times 10^{-3} \mathrm{~m} \mathrm{~s}^{-1}$ shelfward across the shelf break during winter and $2 \times 10^{-3} \mathrm{~m} \mathrm{~s}^{-1}$ during summer. The drifters also sam-
\end{abstract}

Correspondence to: $\mathrm{S}$. A. Thorpe pled local patterns of circulation, and indicate that the source of water for the seasonal Fair Isle and East Shetland currents are the same, and drawn from Atlantic overflows at the Hebrides shelf.

Key words. Oceanography: physical (eastern boundary currents; eddies and mesoscale processes; turbulence, diffusion, and mixing processes).

\section{Introduction}

An intense current flows poleward along and above the Western European continental slope. Transporting around $1 \mathrm{~Sv}$ of warm saline water northward, this slope current is an important contribution to the local circulation of the northern North Atlantic. Current meter records from moorings scattered between the Iberian and Norwegian Shelf edges indicate that flow is persistently contour-following with very little, or intermittent, cross-slope flow (Huthnance, 1986; Pingree and Le Cann, 1989). Whilst drifter studies have hinted at the spatial characteristics of this flow, there have previously been no Lagrangian studies concentrated at the shelf break (Booth, 1988a). This work describes such a study, where releases of 42 drogued drifters during winter and summer $1995 / 6$ have measured the slope current's spatial and seasonal continuity, and quantified the cross-slope exchange between the ocean and the shelf seas.

The Hebrides shelf edge extends from the Hebrides Terrace Seamount at $56^{\circ} \mathrm{N}$, to the Wyville-Thomson Ridge at $60^{\circ} \mathrm{N}$ (Fig. 1). To the west lies the Rockall Trough, with an average depth of $2000 \mathrm{~m}$, and to the east the Hebrides Shelf. At its northern end the WyvilleThomson Ridge with a 'sill' depth of $500 \mathrm{~m}$ separates the Rockall Trough and Faeroe-Shetland Channel, and is a major topographic distortion to the continental 


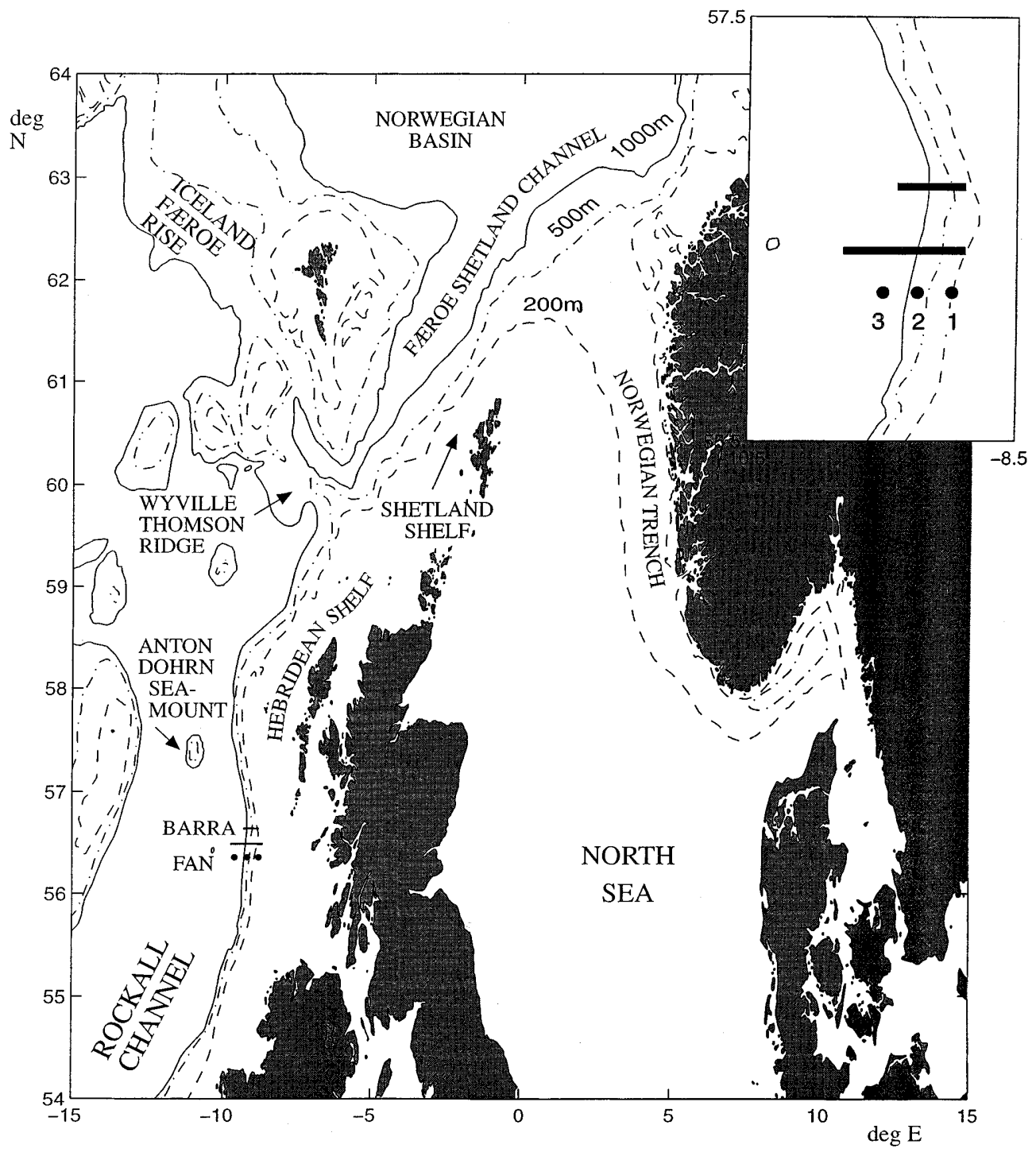

Fig. 1. Bathymetry of the North Atlantic and European Continental Shelf between $54^{\circ} \mathrm{N}, 64^{\circ} \mathrm{N}$, $15^{\circ} \mathrm{W}$ and $15^{\circ} \mathrm{E}$. The slope current flows between the $200 \mathrm{~m}$ (dashed line) and the $1000 \mathrm{~m}$ (solid line) isobaths which delineate the upper and lower slope margins. The $500 \mathrm{~m}$ contour is also shown. Significant bathymetric features; ridges, channels and seamounts, are labelled. The deployment positions of drifters (O) and comparative moored instruments (-) are also illustrated in the expanded section slope. Overall the Hebrides and West Shetland slopes exhibit a rather uniform profile, ranging in steepness from $4^{\circ}$ at the Hebrides slope to $1.5^{\circ}$ at the West Shetland slope. At $58^{\circ} \mathrm{N}$ the Hebrides Shelf edge turns from a north-south orientation to northeast-southwest around a broad slope shoulder.

Warm surface waters flow northward from the North Atlantic Current (NAC), through the Rockall Channel and Faeroe-Shetland Channel, whilst the flow of fresher cold bottom flow originating at high latitude is generally southward (Krauss, 1986). Locally, there is a 4-5 Sv flow in the Rockall Channel, a region of pervasive eddies, toward the Norwegian Sea (Ellett et al., 1986; Huthnance, 1986). An earlier drifter study by Booth (1988) in the Rockall Channel utilised a range of drogue depths from 16 to $166 \mathrm{~m}$. Booth estimates zonal and meridional dispersion to be equal at $3.4 \times 10^{3} \mathrm{~m}^{2} \mathrm{~s}^{-1}$. The general drift was to the northeast. His results also show the characteristics of the intensified slope current on the western boundary. Drifters deployed in the NAC encounter the eastern boundary of the Rockall Channel with a mean approach velocity of about $0.02 \mathrm{~m} \mathrm{~s}^{-1}$ (Pingree, 1993).

Persistent along-slope flow has been observed over the Hebrides and Shetland slope by Carter et al. (1987). The mean velocities at all moorings over the continental slope between the Anton Dohrn Seamount and the West Shetland slope are poleward along-slope, parallel to the local contours at all depths. This current is intensified over the $500 \mathrm{~m}$ slope contour, and in the upper $200 \mathrm{~m}$. It increases in speed with latitude, from $0.15 \mathrm{~m} \mathrm{~s}^{-1}$ at $56^{\circ} \mathrm{N}$ to $0.50 \mathrm{~m} \mathrm{~s}^{-1}$ at $62^{\circ} \mathrm{N}$. Along-slope flow is generally considerably stronger than across-slope flow and the mean flow is usually stronger than the tidal flow. At the Wyville-Thomson Ridge the current is principally across contour and poleward, with a wide range of directions with depth.

Current meter data collated for the Hebrides slope and the Celtic slope indicate increasing transport with latitude, $0.6 \mathrm{~Sv}$ at the Celtic slope, increasing to approximately $1.5 \mathrm{~Sv}$ at the Hebrides slope and 4-7 Sv along the Shetland Shelf. Increased transports in a 
slope-confined current indicate entrainment of oceanic waters into an accelerating current (Huthnance, 1986).

Circulation on the Northern European Shelves has been extensively studied. Booth and Ellett (1983) and Simpson and Hill (1986) observed the Scottish Coastal Current which is a northward-flowing buoyancy driven current with pronounced bottom steering, particularly in the Minch where the current bifurcates. Svendsen et al. (1990), Turrell and Henderson (1990) and Turrell (1992) have studied the circulation of the North Sea and its interaction with the Shetland Shelf via the Fair Isle and East Shetland Currents. Features of the local circulation patterns, particularly those associated with the local trapping of water, have been observed (e.g. Hill et al., 1994; Hill, 1993). These include the seasonal cyclonic gyres of the Irish Sea caused by the deformation of cold dense bathymetrically constrained bottom water, a feature which may also occur in the North Sea and the Minch.

Certain continental shelves have identifiable fronts aligned over the shelf break e.g. the Mid-Atlantic Bight where cool fresh shelf waters are clearly separated from warmer saltier slope waters, indicating blocking of cross slope fluxes (Garvine et al., 1989). Pingree and Mardell (1981) show satellite imagery of the western limit of the spring coccolithophore bloom clearly aligned above the Hebrides shelf break suggesting the presence of a stratification front. There is however no decisive evidence of any shelf break alignment of fronts off the Hebrides. The identification of such physical features is of importance in assessing the balance of mixing and blocking mechanisms.

The instruments used and experimental procedure are described in Sect. 2. In Sect. 3 we examine the slope current. The related local circulation is addressed in Sect. 4. Analysis of variability, dispersion and crossslope fluxes are discussed in Sects. 5, 6 and 7. Italic summer and winter have been used in the text to help discriminate between summer and winter observations.

\section{Instrumentation}

\subsection{Drifters}

During the winter and summer of 1995/6, 42 instrumented drifters, tracked by ARGOS and drogued at $50 \mathrm{~m}$, were deployed over the Hebrides slope to define the mean motion at, and to estimate dispersion around, the shelf break, and to seek evidence of processes leading to transport at the shelf break. A preliminary description of the experiment is given by Burrows et al. (1998). Here we describe the seasonal variation of shelf edge flows and nearby circulation revealed by the drifters.

To facilitate comparison with other instruments, WOCE standard drifters were chosen (Sybrandy and Niiler, 1991; Niiler et al., 1995). These are easily and economically available, and have proved to be an accurate and robust surface layer instrument. Each drifter is drogued at $50 \mathrm{~m}$ with a weighted 'Holey-sock' drogue. The drogue is suspended by a steel cable from a small subsurface float at approximately $1 \mathrm{~m}$ depth. This is linked to the surface float, which houses the satellite tracking antenna and sensor electronics. Drifter locations are measured by ARGOS satellites to an accuracy of $0.5 \mathrm{~km}$, every $2 \mathrm{~h}$, except for a gap in coverage at Hebridean latitudes of about $2 \mathrm{~h}$ around midnight. Drifters were equipped to measure sea-surface temperature, either during the satellite overpass to a resolution of $0.4 \mathrm{~K}$, or with a period of $15 \mathrm{~min}$ to a resolution of $0.04 \mathrm{~K}$. The higher resolution instruments were accompanied by similar drogue-top temperature measurements, and pressure sensors, but these unfortunately proved too fragile for the oceanographic conditions.

\subsection{Instrumental bias}

Instrumental bias is inevitable in the presence of wind, waves and vertical water movement. This instrumental error has been characterised by Niiler et al. (1995). For our drifters drogued at $50 \mathrm{~m}$, with a $30: 1 \mathrm{drag}$ area ratio, the expected water-following error is $1.7 \mathrm{~cm} \mathrm{~s}^{-1}$ in $10 \mathrm{~m} \mathrm{~s}^{-1}$ winds. Additionally slippage is caused by kiting and feathering, which affect the depth and attitude of the drogue (Chereskin et al., 1989). Drogue weighting reduces the kiting, or drogue rise, to $0.20 \mathrm{~m}$. Some high frequency motion from surface waves is suppressed by decorrelating the surface float from the drogue with subsurface buoyancy. This also allows the satellite antenna to remain above the water surface.

Davis (1985) has discussed the use of drifters in making both Eulerian and Lagrangian time average measurements of the velocity field. Lagrangian paths are biased in favour of high velocities e.g. at convergent fronts. This indicates that the drifters' instantaneous velocity is closely determined by the drifters' history over times of the order of the Lagrangian velocitycorrelation time scale, $\tau_{0}$, which is estimated in Sect. 5.2. In principle Eulerian averages will also be biased toward higher velocities to an extent which cannot be estimated. The slope current is convergent over scales $\mathrm{O}\left(10^{4} \mathrm{~km}\right)$. However, as will be discussed, the velocity-correlation time scales are relative short indicating that the Lagrangian bias is relatively small. Comparison with current meters moored at $50 \mathrm{~m}$ over the Hebrides slope show currents which agree to $\pm 1 \mathrm{~cm} \mathrm{~s}^{-1}$ for separations of less than $5 \mathrm{~km}$.

\subsection{Data processing}

The drifter data is first filtered for drogue loss. Summer drifters were equipped with a submergence gauge which indicates zero submergence after drogue loss. Drogue loss for winter drifters is inferred from a sustained increase in the variance of velocity and sea-surface temperature. This has been tested; it proves to be a successful identifier of drogue loss when applied to summer drifters.

A 2 hourly interpolated time series is obtained for each drifter from satellite positions obtained at similar 
but irregular intervals. A Cherbyshev polynomial fit, of order between 1 and 40 chosen to give minimal differential least squared error, is sought for each interpolated position, spanning approximately 20 surrounding raw positions weighted by a $40 \mathrm{~h} \cos ^{2}$ curve (Krogh, 1970). Instantaneous velocities are calculated as differentials of the fitted polynomials. The time series are despiked by eliminating all interpolated velocity components, or those inferred by a linear calculation of velocity from interpolated positions, exceeding $1.0 \mathrm{~m} \mathrm{~s}^{-1}$. Additional position time series were calculated in a coordinate axis in which the distances along and normal to the slope are measured respectively parallel to and normal to the local direction of the $500 \mathrm{~m}$ contour using digitized IOS bathmetry (Roberts et al., 1977). These velocity components constitute statistically independent variables as the contour is the principle axis of the slope current, and shelf edge Reynolds stresses (see Sects. 3.1 and 5.1). The smallest distance between the drifter and the contour defines the across-slope distance, $X$, see Fig. 2. The along-slope position, $Y$, of a drifter is the length of the contour between the deployment and

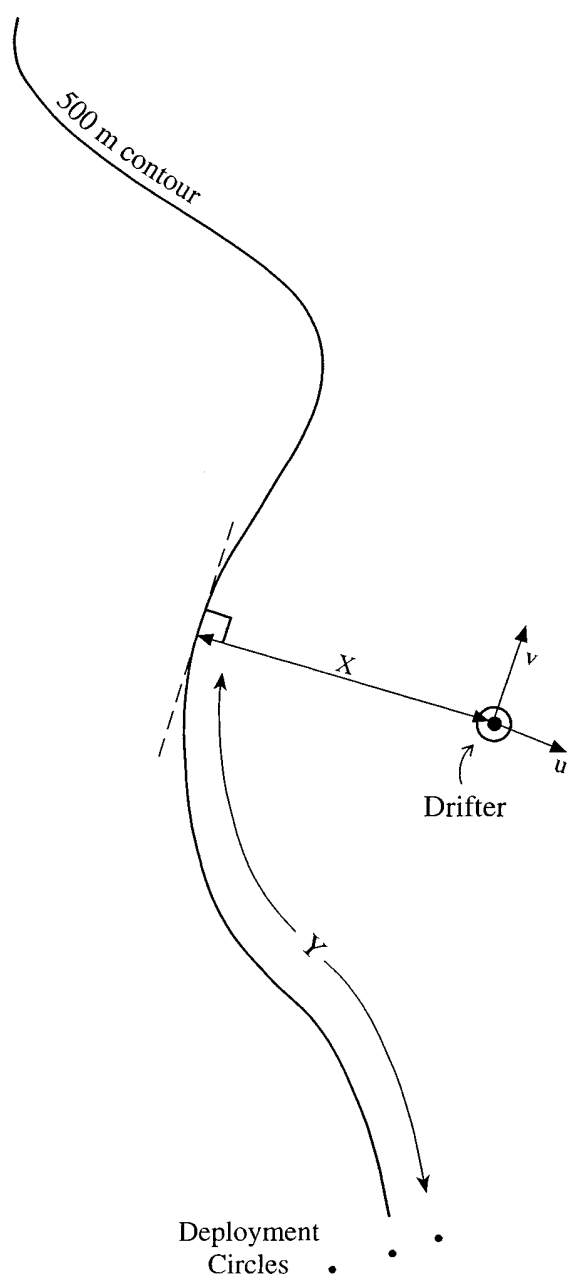

Fig. 2. Sketch of the across-slope, $X$, and along-slope, $Y$, positions and across-slope, $u$, and along-slope, $v$, speed components of drifters relative to the $500 \mathrm{~m}$ isobath and the release site. The coordinate $X$ is measured normal to the nearest $500 \mathrm{~m}$ isobath the drifter position. A conservative estimate of position resolution is $2 \mathrm{~km}$, approximating the average length of line elements on the IOS chart. Along and across-slope components of velocity, $v$ and $u$, are measured in the direction of and normal to the local contour. The velocity time series has been filtered for tides with a 10th order zero phase Butterworth low pass filter with cut-off at $1 \mathrm{cyc} /$ day. This effectively attenuates diurnal and higher frequencies which are tidally variable in amplitude and phase across the Hebrides and Shetland Shelves.

Two hourly average wind speed from Stornoway, on the Isle of Lewis are used in meteorological analyses. Where stated in the text meteorological data has also been taken from the Tiree and Fair Isle weather stations.

\subsection{Deployment}

Drifter deployments were made on the 4 December 1995 and 5-9 May 1996 so that unstratified winter and stratified summer conditions can be compared. In each deployment, circles of seven drifters were placed over the upper slope (200-400 m isobaths, circle 1), mid-slope (500-700 m isobaths, circle 2) and deep slope (1000$1200 \mathrm{~m}$ isobaths, circle 3) (see Fig. 1). The three circles gave a total across-slope spread of $20 \mathrm{~km}$. These locations corresponded to areas inshore, over and offshore of the slope current core. CTD casts were taken at each circle concurrent with its deployment. Deployments were at $56^{\circ} 15^{\prime} \mathrm{N}$ in a region of relatively uniform slope. The location was some $25 \mathrm{~km}$ south of an extensively instrumented LOIS SES (see acknowledgements) moored array.

\section{The slope current}

\subsection{Structure}

The slope current flows poleward along the Hebridean shelf throughout the summer and winter deployments. The current is evident as flow along isobaths, and is the strongest and most persistent current in the region as shown in the drifter tracks of Fig. 3 (winter release) and Fig. 4 (summer release). These figures are divided into 25 day sections (Figs. 3, 4a-d) covering the first 100 days after release and so characterising the periods of winter and summer, and (Figs. 3, 4e) 240 days. These form the basis of detailed discussion in subsequent sections.

Figure 5 shows the winter and summer across-slope profiles of along and across-slope velocity, averaged over two successive 40 day periods, days $0-40$ and 40 80 , in $5 \mathrm{~km}$ across-slope bins. The first 40 day average includes only measured velocities south of the WyvilleThomson Ridge, and in the second only measurements to its north, a division which closely corresponds to the distribution of drifters during the two periods. The maximum mean slope current is located between 0 and 

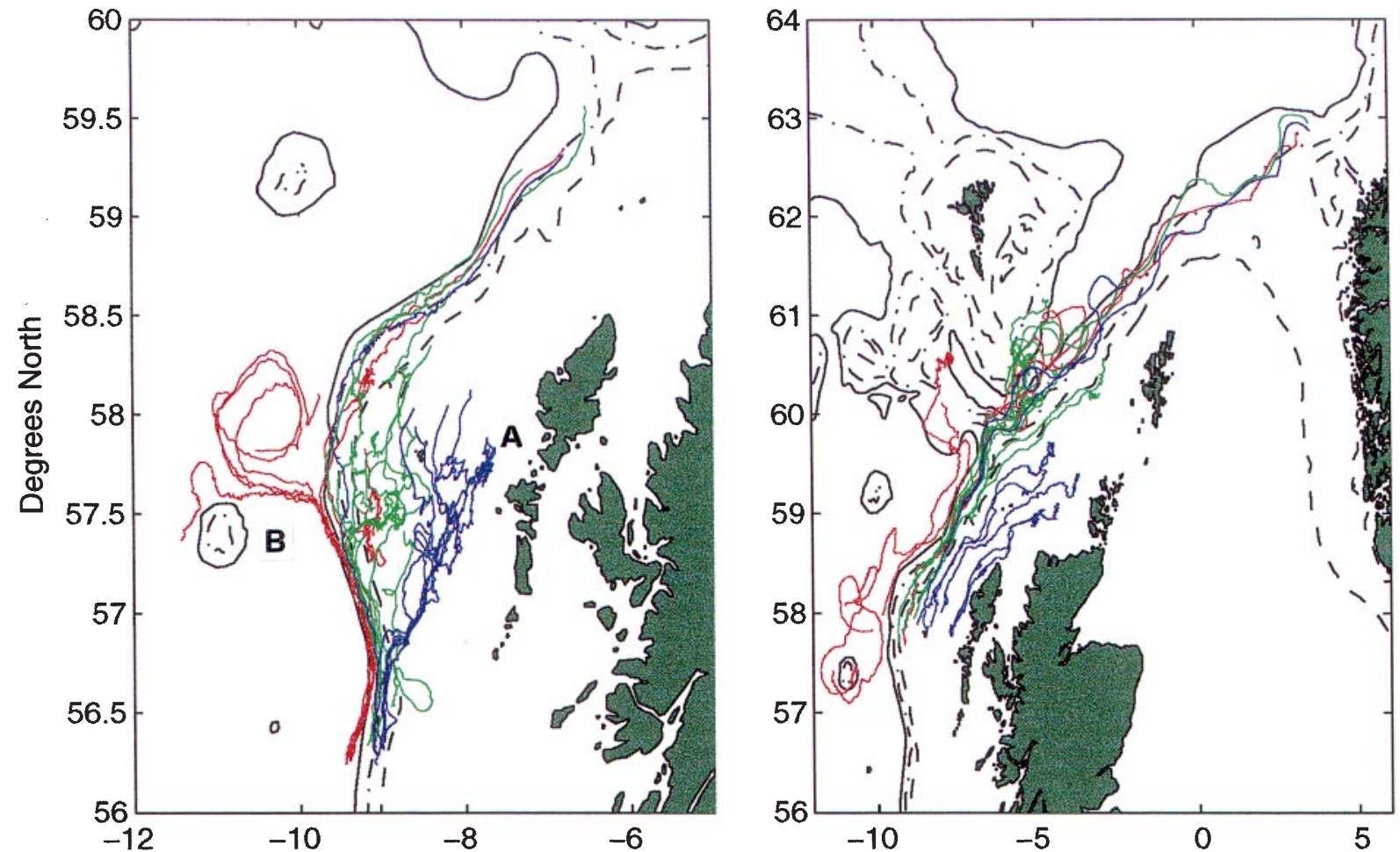

a

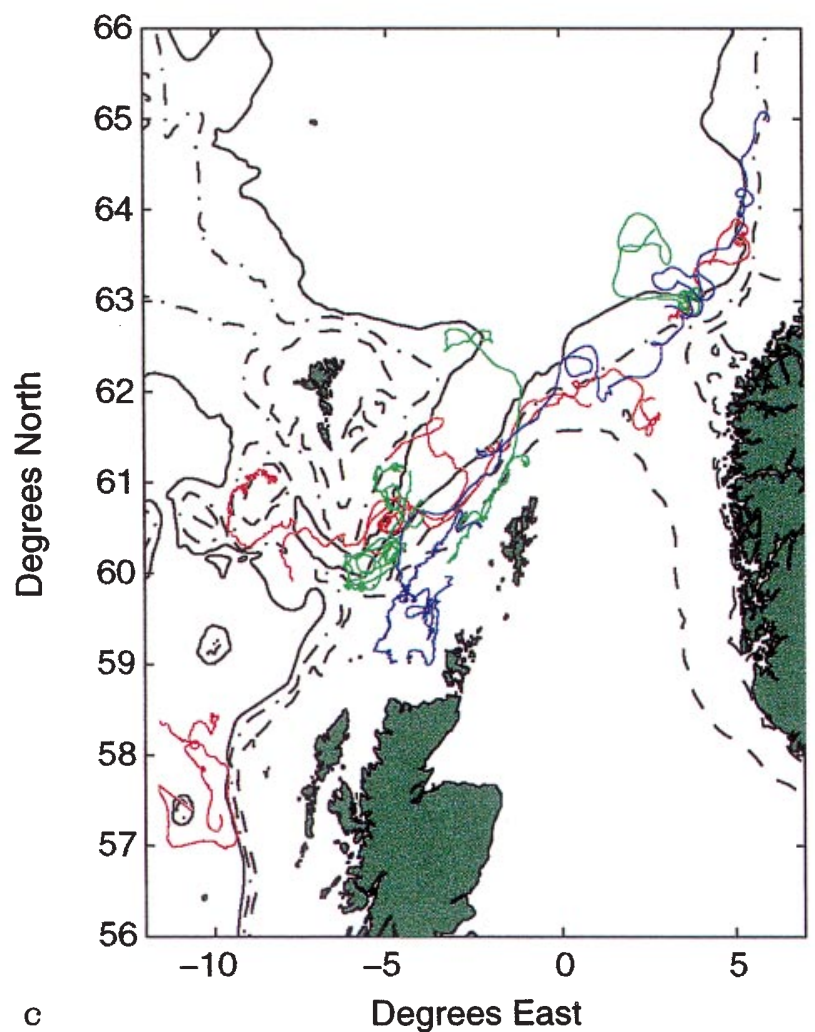

b

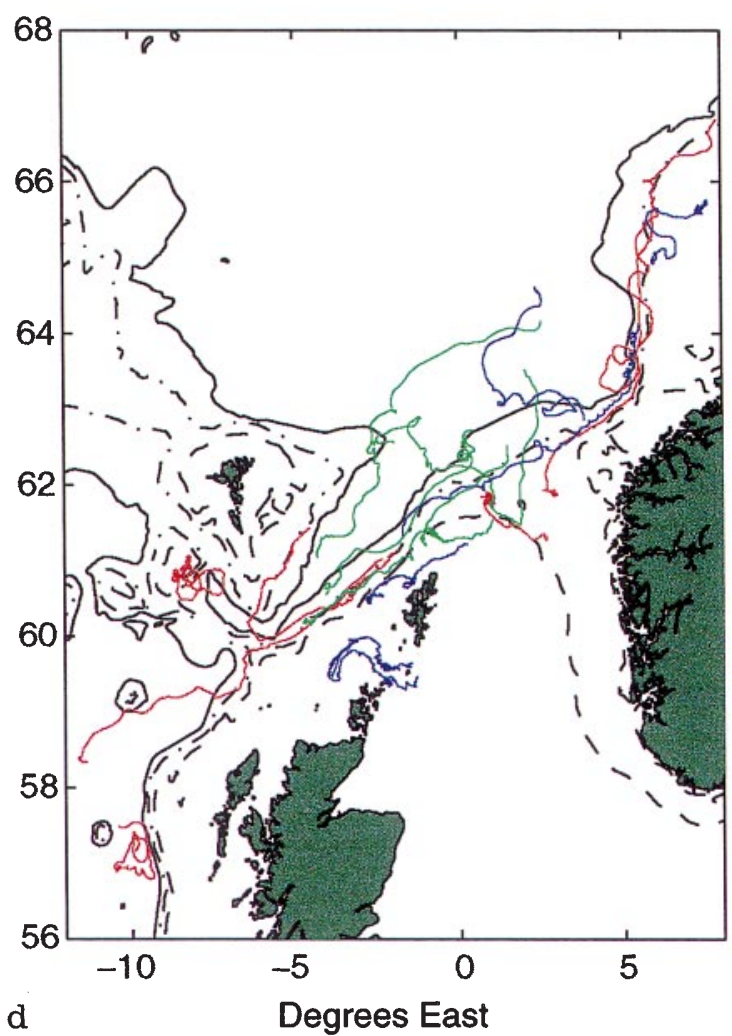

Fig. 3a-e. Drifter tracks after the winter deployment on 4 December 1995, in 25 day sections. Circle 1 drifters are blue, circle 2 green, and circle $3 \mathrm{red}$. a 0-25 days, b 25-50 days, c 50-75 days and d 75-100 days. The scale increases with frame. e Are the complete drifter tracks over

the 240 days after each deployment. In a, $A$ indicates a position of relative stagnation, and $B$ marks the bifurcation of the slope current near the Anton Dohrn Seamount 


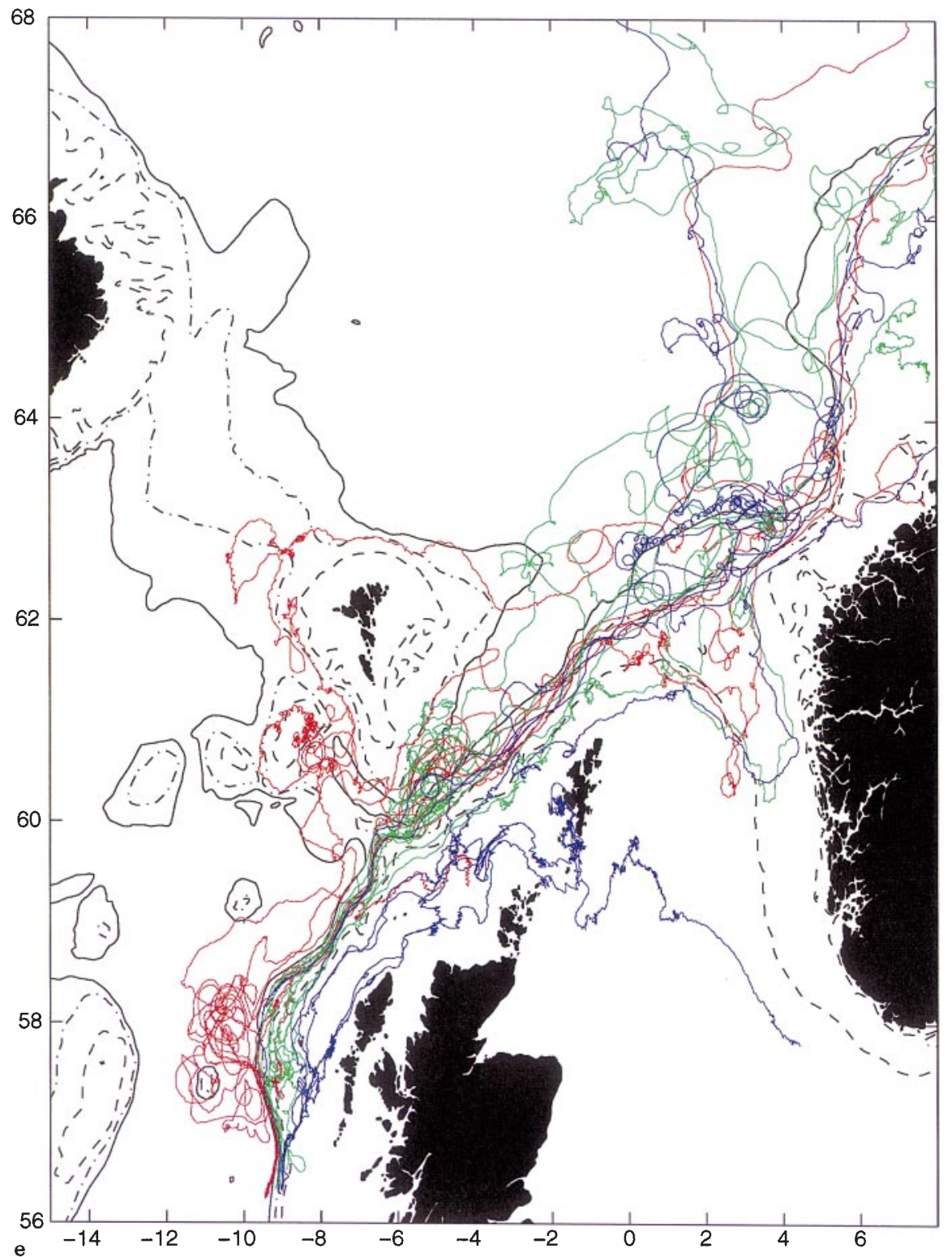

Fig. 3e.

$15 \mathrm{~km}$ oceanward of the $500 \mathrm{~m}$ contour. The current is $25 \mathrm{~km}$ wide at the Hebrides slope. The profile there in winter, Fig. $5 \mathrm{a}$, is slightly widened by $5-10 \mathrm{~km}$ meanders (see Fig. 3a at the Hebrides slope). The summer jet also meanders (see Sect. 3.3 and Fig. 6). The largest mean along-slope speeds are $0.3 \mathrm{~m} \mathrm{~s}^{-1}$ during winter and $0.25 \mathrm{~m} \mathrm{~s}^{-1}$ in summer. Beyond the Ridge in winter (Fig. 5b) the current is broadened by vigorous eddies in the Faeroe Shetland Channel. Transport in the surface layer is increased in this region with a jet width of $55 \mathrm{~km}$, and an along-slope mean velocity of $0.27 \mathrm{~m} \mathrm{~s}^{-1}$. Across-slope velocities are divergent (i.e. negative in water deeper than $500 \mathrm{~m}$ and positive in shallower) and not measurably different from zero at the core of the jet throughout both seasons. During the summer there is stagnation and a large velocity gradient over the outer $20 \mathrm{~km}$ of the shelf (e.g. see later discussion of Fig. 11f), with zero onshelf velocity observed during a period of oceanward movement from the western edge of the jet.

The jet speed over the Hebrides slope is variable between $0.05 \mathrm{~m} \mathrm{~s}^{-1}$ around the slope shoulder at $58^{\circ} \mathrm{N}$ and $0.50 \mathrm{~m} \mathrm{~s}^{-1}$ to the south of the Wyville-Thomson Ridge. The along-slope component immediately to the northwest of the Ridge was not measurably different from zero during the winter. After some convoluted transport along the Faeroe-Shetland Channel the drifters become re-entrained in the current $150 \mathrm{~km}$ alongslope from the Ridge. Along the Shetland slope the current speed increases from $0.50 \mathrm{~m} \mathrm{~s}^{-1}$ to $0.70 \mathrm{~m} \mathrm{~s}^{-1}$, with velocities here somewhat higher than the spatial average (see Fig. 5b). During winter the current is evident for over $2000 \mathrm{~km}$ (see Fig. 3e).

Sea-surface temperature measurements show minima of the same dimensions and location as the current core. During winter the temperature minimum is persistently 

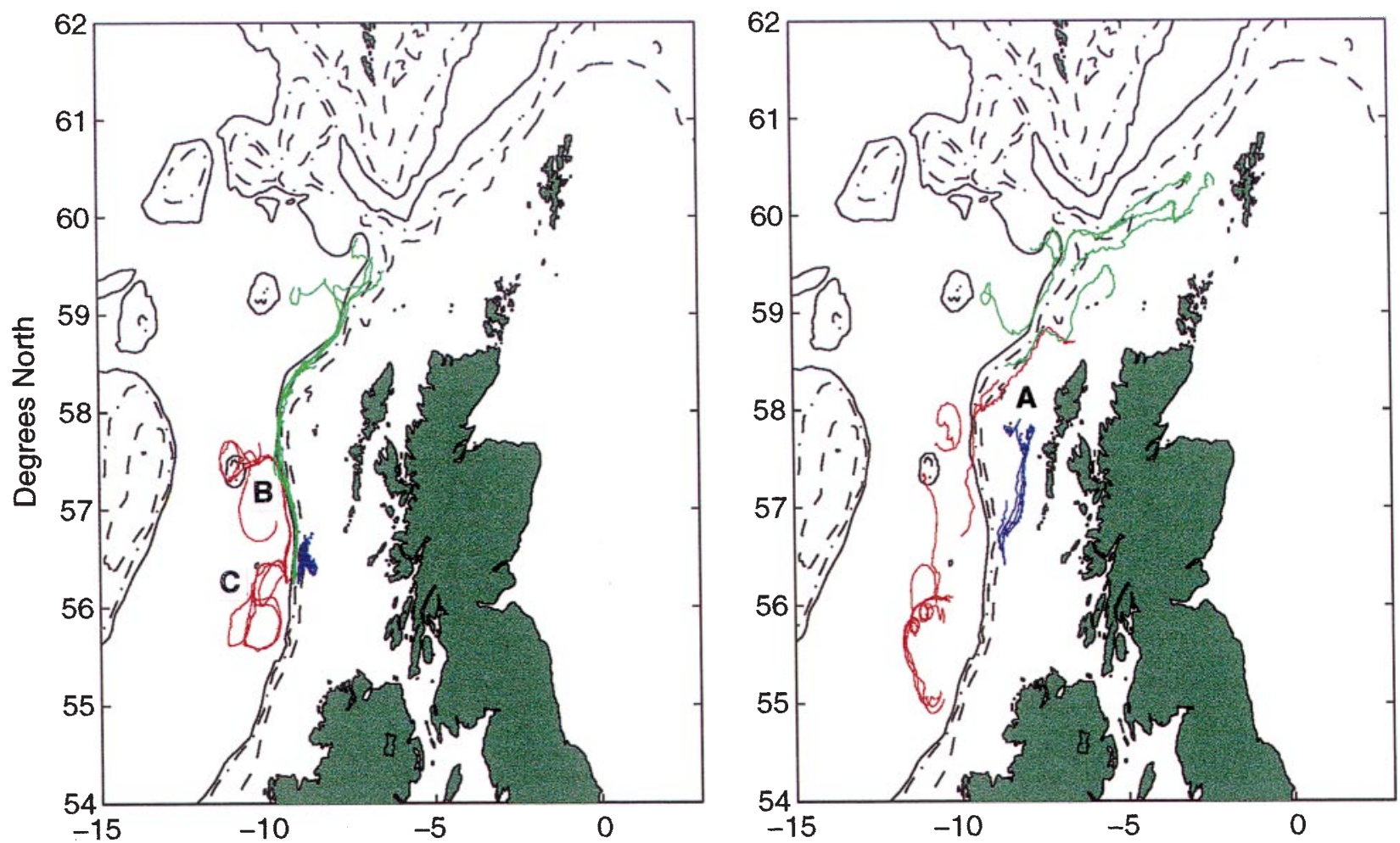

a

$\mathrm{b}$
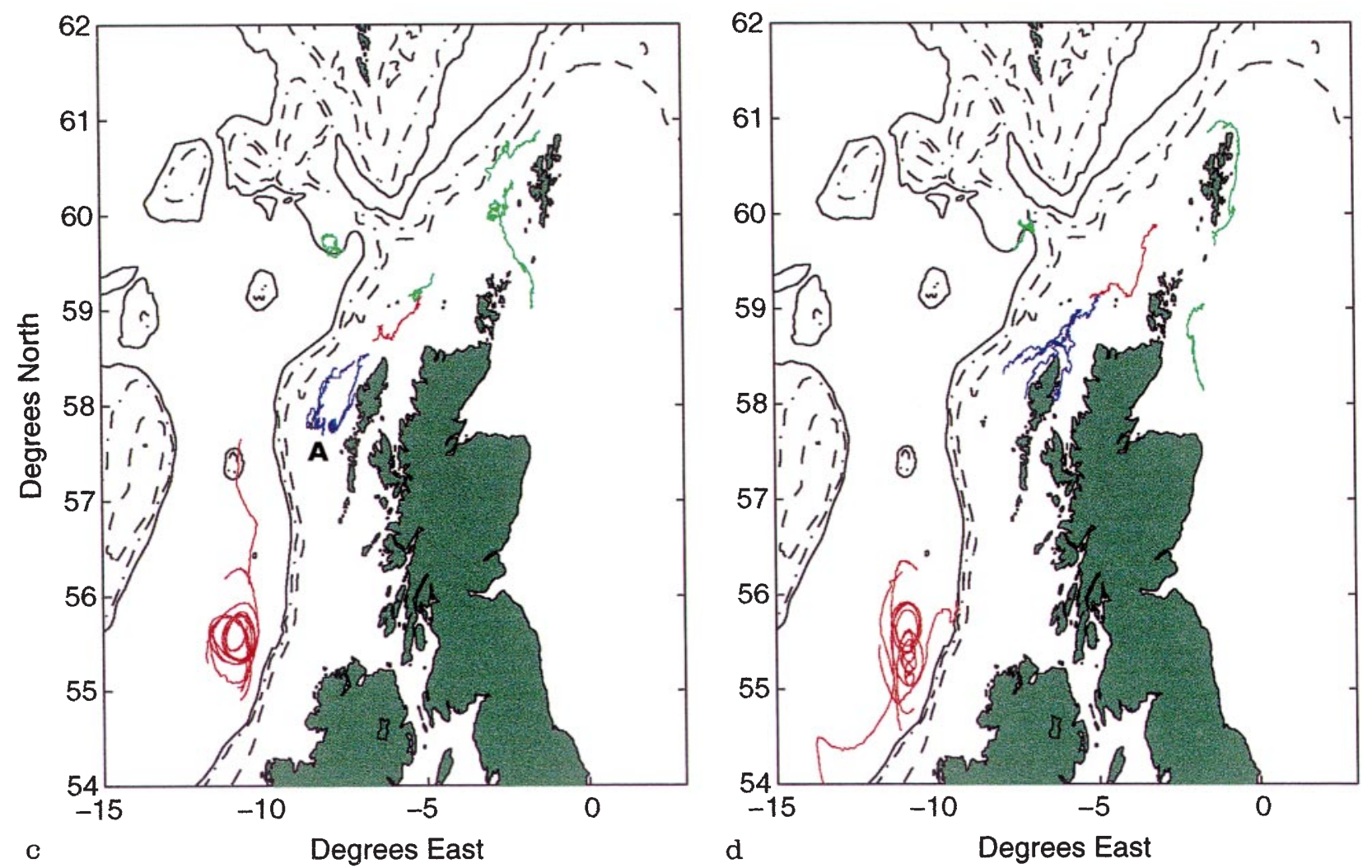

Fig. 4a-e. Drifter tracks after the summer deployment on 5-9 May 1996, in 25 day sections. The frames remain on the same scale but are in other respects identical to Fig. 3. $C$, In a marks dispersion near the Barra Fan 


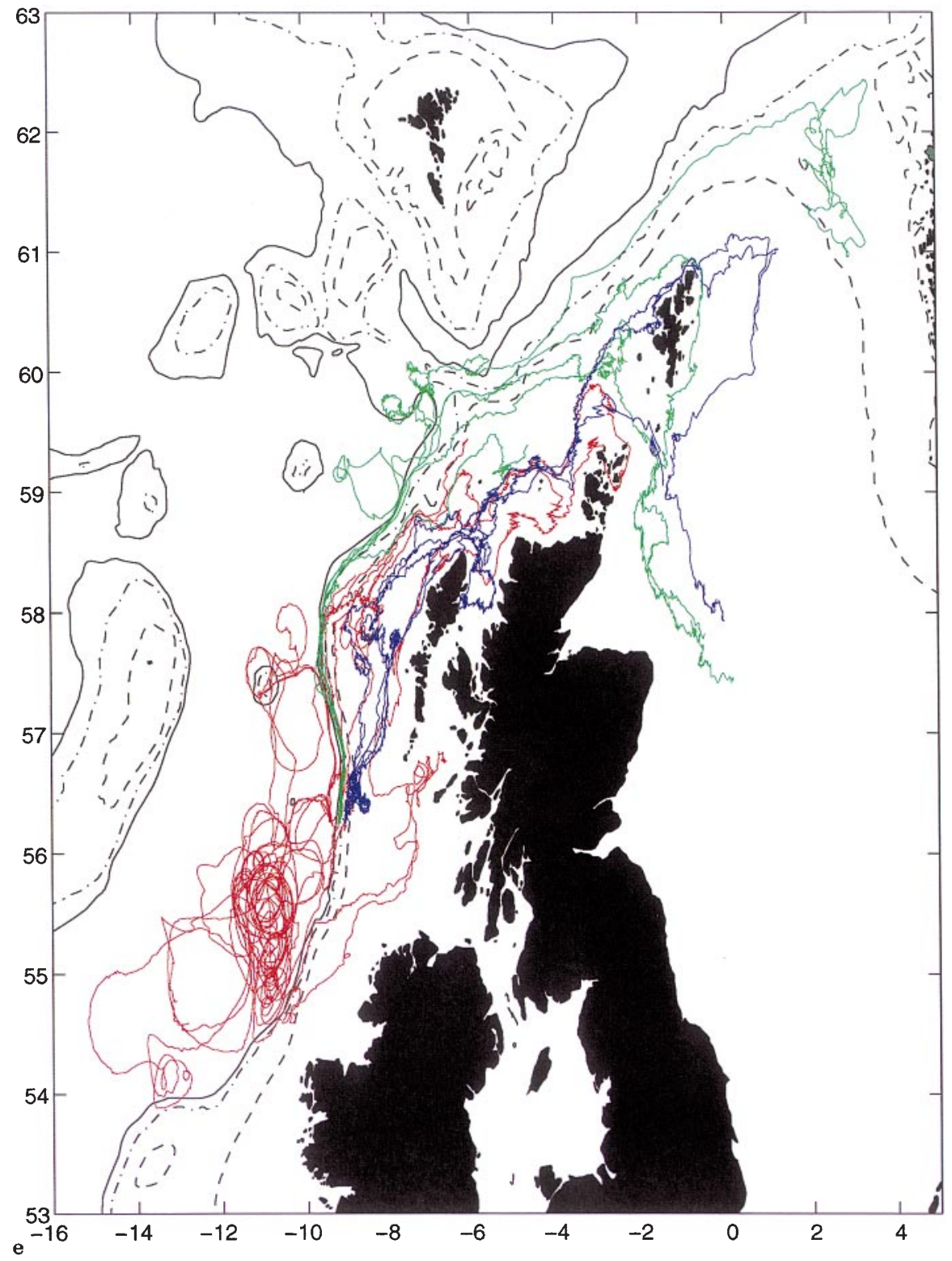

Fig. 4e.

$0.4-0.7 \mathrm{~K}$ below the large-scale average and is located between 0 and $15 \mathrm{~km}$ east of the current shown in Fig. 5a. During the summer the temperature deviation is $0.2-0.6 \mathrm{~K}$, and is evident over the slope current.

\subsection{Meteorological forcing}

Winds exceeding $10 \mathrm{~m} \mathrm{~s}^{-1}$ occurred over the Hebrides slope during the first 100 days after release in both seasons. During days 25 to 45 of the winter deployment winds are $10-15 \mathrm{~m} \mathrm{~s}^{-1}$ and from $180^{\circ} \pm 45^{\circ} \mathrm{N}$. Slope drifters are then approaching the Wyville-Thomson Ridge and shelf and ocean drifters lie adjacent to the slope shoulder. The observed response of the ocean to strong winds is that an along-slope flow is generated over the whole region. The trapping eddies and stagnations (areas of persistently low drift) in deep and shallow waters collapse, and along-slope flow becomes more intense. The average kinetic energy of all the drifters increases by a factor greater than 3 (compare Fig. 3a, b).

A similar wind event occurs during summer between days 23 and 37 , with persistent $300^{\circ} \pm 25^{\circ} \mathrm{N}$ winds reaching $15 \mathrm{~m} \mathrm{~s}^{-1}$, and leads to the termination of the stagnation regions on the shelf near the shelf break (Fig. 4a, b).

The wind forcing has been quantified by the least squares regression of along and across-slope velocity on north and east components of wind velocity, whilst drifters are to the south of the Wyville-Thomson Ridge. During summer the wind-forced currents are small. The coefficient $c_{Y}=V_{\text {drifter }} / V_{\text {wind }}$, the ratio of the drifter to wind components parallel to the $500 \mathrm{~m}$ isobath (i.e. in the $Y$ direction) and similarly $c_{X}$, are of the order of the uncertainty in the water-following ability of the drifters. Product moment correlations are also small in both along and across-slope directions. The mixed layer 

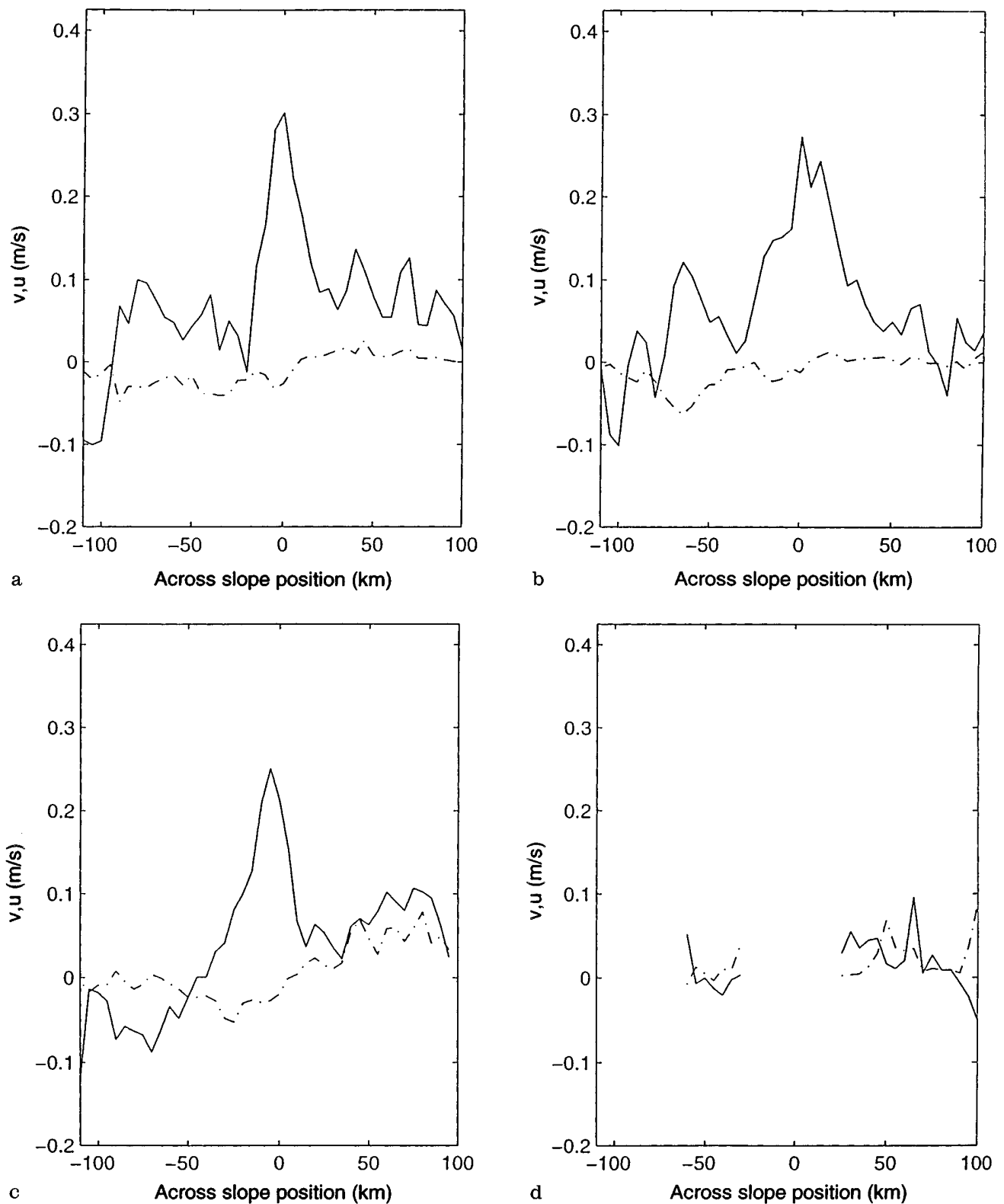

Fig. 5a-d. Average along-slope, $Y$, (solid line) and across-slope, $X$, (dot-dashed) velocity profiles during a, b winter and c, d summer adjacent to the a, $\mathbf{c}$ Hebrides and $\mathbf{b}, \mathbf{d}$ Shetland Shelf breaks for days

0-40 and 40-80 after deployment. Measurements are averaged in $5 \mathrm{~km}$ bins of across-slope distance

depth over the slope at $56.5^{\circ} \mathrm{N}$ on 11 May, day 5, was about $25 \mathrm{~m}$ and it is likely that stratification above $50 \mathrm{~m}$ decorrelates currents measured by the drogues at that depth from the surface forcing. Winter drifters however have a wind-correlated velocity component. The slope region is more responsive to wind forcing than the shelf and ocean, with $\left[c_{Y}, c_{X}\right]=[0.0144,0],[0.0081,0.0037]$ and $[0.0037,-0.0012]$ for the three regions of slope, shelf and ocean, respectively. These imply, for example, that the slope region may be forced at $0.14 \mathrm{~m} \mathrm{~s}^{-1}$ in a 10 $\mathrm{m} \mathrm{s}^{-1}$ wind, with a correlation coefficient of 0.46 . These transient flows are in excess of background slope currents. Across-slope winds did not generate any mean across-slope flow over the slope.

\subsection{Continuity}

Drifters passed along the Hebrides slope, East Shetland slope, Norwegian Trench and Norwegian slope. The slope current is continuous along the Hebrides slope throughout the first 40 days of summer and winter deployments, and on the East Shetland slope during the winter when there is a break in continuity of transport along the slope beyond the Wyville-Thomson Ridge (see Figs. 3b, c, and 11a). Drifters leave the slope region in an area of no measurable along-slope flow. The slope current on the Shetland slope was continuous and linked to the Norwegian slope and Norwegian Trench currents. 

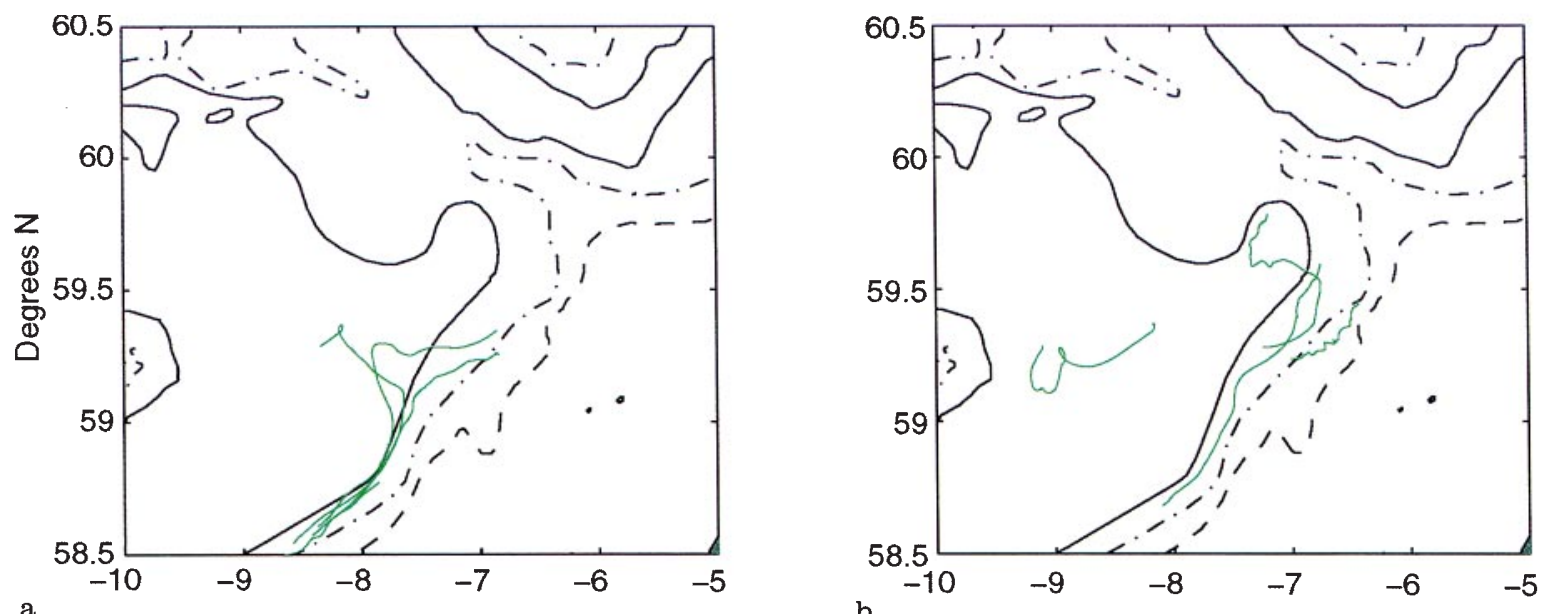

a
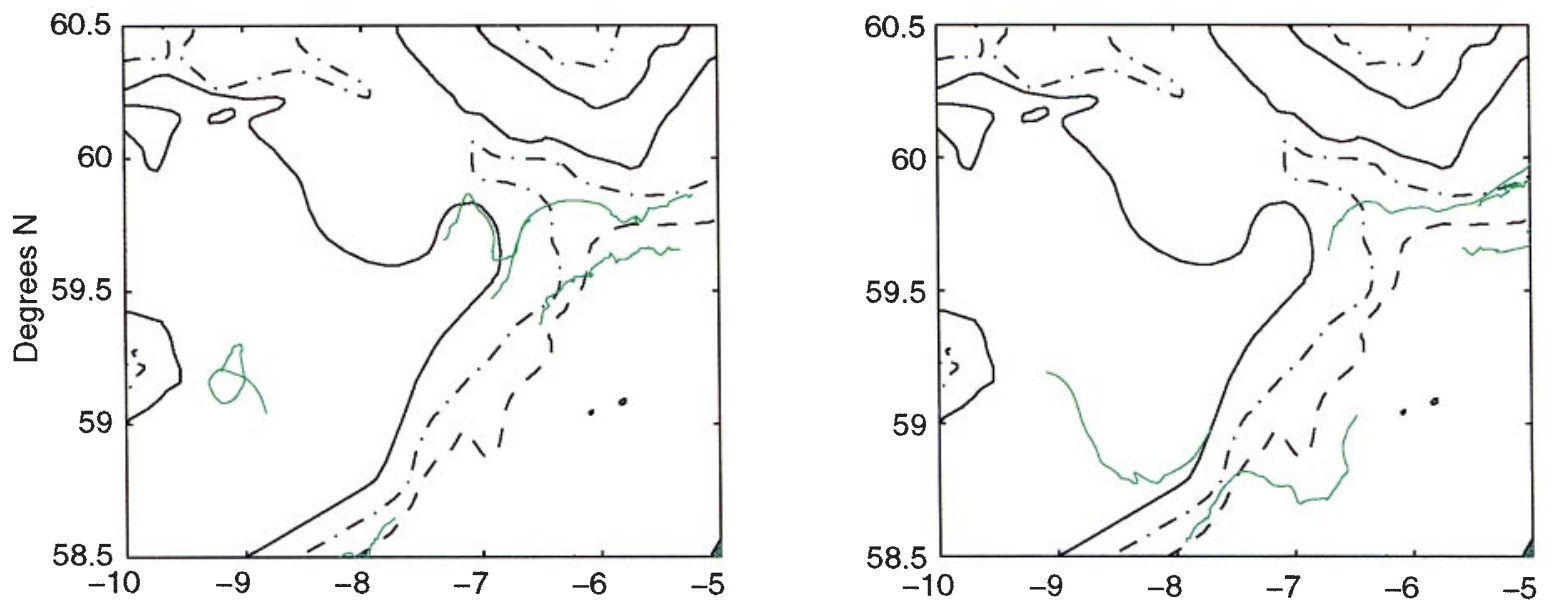

c

d
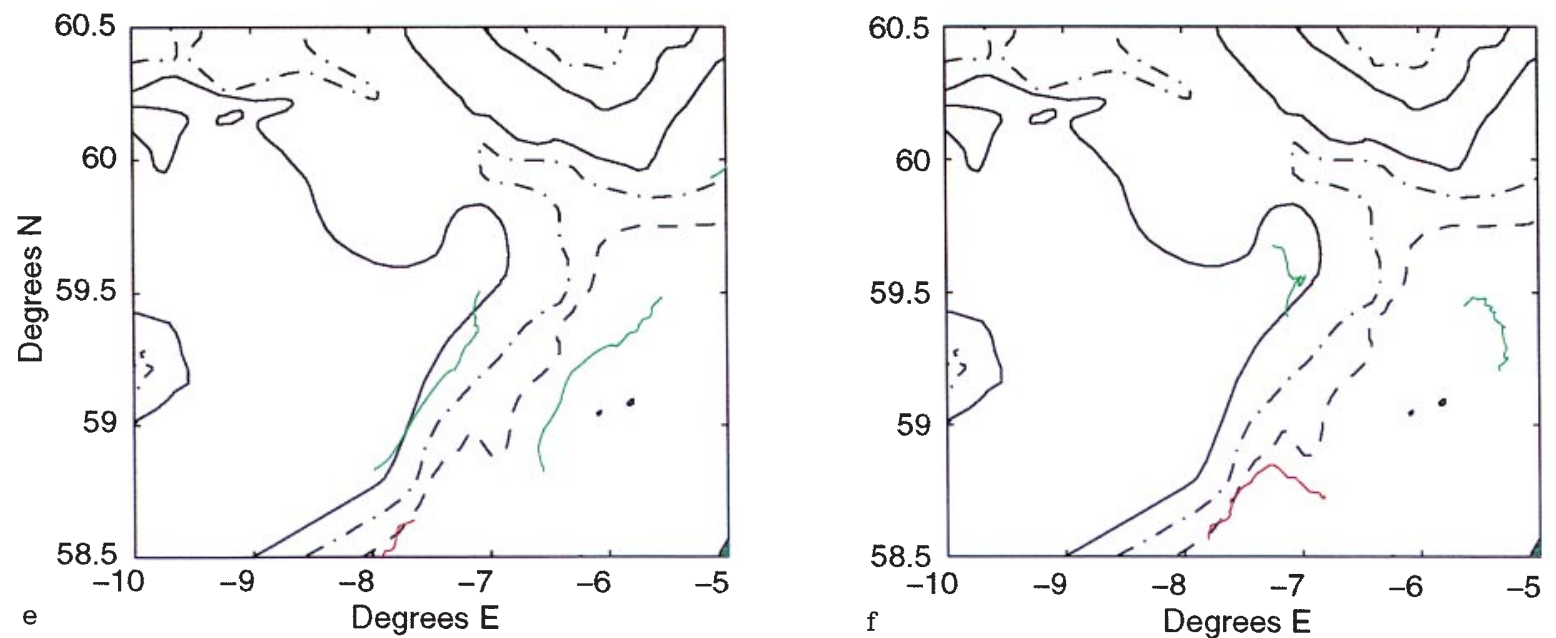

Fig. 6a-f. Drifter tracks south of the Wyville-Thomson Ridge after day 15 of the summer deployment, in sequential 5 day sections, a-f. Drifters are coloured as in Fig. 3

On day 15 of the summer deployment the previously confined and stable slope current begins to meander immediately to the south of the Wyville-Thomson Ridge. Figure 6 shows sequential 5 day periods. Three circle 2 drifters loop $50 \mathrm{~km}$ into deeper waters for 3 days (Fig. 6a). After a second meander over deeper waters (Fig. 6b) drifters pass onto the shelf across the whole Hebrides slope (Fig. 6c-f), where the meandering 
stops, leaving the Hebrides slope completely without drifters. There are, in consequence, no drifters in the slope current at the edge of the East Shetland shelf during the second and third months after the summer deployment (see Fig. 4c, d). During the whole of this period a drifter remains almost stationary over the Wyville-Thomson Ridge suggesting, at least there, the absence of a slope current. Unfortunately with the loss of drogue-top temperature measurements (Sect. 2.1) no definitive statements about the local state of stratification can be made. Thermistor chains over the slope at the LOIS SES moored array at $56.5^{\circ} \mathrm{N}$ (Fig. 1) however show a continuous increase in the mixed layer thickness, and reaching drogue depths 45 days after release. The slope current was detected again by drifters on day 115 .

\subsection{Stability}

Along much of the path of the slope current there are no meanders or eddies (e.g. Huthnance, 1995) with wavelengths less than $\mathrm{O}\left(10^{5} \mathrm{~m}\right)$. There are however two areas of notable variability, in the lee of the WyvilleThomson Ridge, and at the mouth of the Norwegian Trench (see Fig. 3). In winter drifters flowed over the Wyville-Thomson Ridge (see Sect. 3.3 and Fig. 3b). Over the Ridge the drifters are diverted toward the Ridge axis, flowing northwestward down the Ridge, and into deeper waters to its northeast. The most westerly drifter initially flowing west of the $1000 \mathrm{~m}$ contour does not cross the Ridge and stagnates for several months over the Faeroe Bank. Those flowing over the Ridge are not carried by any coherent slope current in its lee, and overflow the Ridge into water of over $1000 \mathrm{~m}$, the region of energetic eddies (Sect. 3.1). These eddies of around $50 \mathrm{~km}$ diameter pervade the southernmost part of the Faeroe-Shetland Channel, circulating both cyclonically and anticyclonically with speeds up to 1.20 $\mathrm{m} \mathrm{s}^{-1}$. There is a slow and circuitous along-slope movement with drifters taking between 8 and 80 days to re-enter the slope current $150 \mathrm{~km}$ along-slope from the Ridge. Eddies are superimposed on the contourfollowing slope current at the intersection of the FaeroeShetland Channel and the Norwegian Trench (see Fig. 3e). The eddies persisted beyond the Trench to $64^{\circ} \mathrm{N}$. During summer there were no areas with notable variability other than those shown in Fig. 6.

\section{Local patterns of circulation}

Figures 7 and 8 show the seasonal mean currents observed by the drifters averaged in $50 \mathrm{~km}$ boxes over 180 days after the winter and summer deployment, respectively. There are periods of flow reversal and stagnation in high and low winds, respectively, persisting for between 3 and 6 days (e.g. Figs. 3 and 4 at points A). The currents and their directions near the edge of the Hebrides shelf are sometimes variable (e.g. see Figs. 11f and 3a), whilst near the edge of the Shetland shelf the currents are persistently poleward along-slope (e.g. see Figs. 3b, 4c). Drifters on the West Shetland Shelf approach the Norwegian Trench and cross the shelf edge (Fig. 3e). The drifters turn toward the north within $200 \mathrm{~km}$ of the northern end of the Trench during winter to become a northward current flowing on its eastern margin.

Flow over deeper areas are also generally northward, through the Rockall Channel, to the Faeroe-Shetland Channel via the Wyville Thomson Ridge and from there into the Norwegian Basin. During winter the strongest flows encountered in the Rockall Channel are the Anton Dohrn Seamount eddies. The period of the anticyclonic eddy (Fig. 3a) north of the Seamount is $7.5 \pm 3$ days with currents of $0.2-0.25 \mathrm{~m} \mathrm{~s}^{-1}$. A cyclonic eddy overlies the Seamount with a circulation period of approximately 30 days (Fig. 3e). Booth (1988b) has described these eddies as Taylor columns. There was no evidence of eddy detachment as drifters were advected out of this region during gale force winds. Summer drifters were entrained into an anticyclonic eddy to the north of the Seamount with a circulation period of $8 \pm 3$ days and speeds of $0.1 \pm 0.05 \mathrm{~m} \mathrm{~s}^{-1}$, and a cyclonic eddy with period of 6 days and speeds of $0.2-0.3 \mathrm{~m} \mathrm{~s}^{-1}$ overlying the Seamount (Fig. 4a, b). The northern eddy reversed polarity after half a cycle.

The drifters are generally well-spaced on the Shetland Shelf, having been dispersed by Hebrides Shelf break or Wyville-Thomson overflows. They converge toward the $100 \mathrm{~m}$ contour on the north-western side of the OrkneyShetland Ridge (Fig. 9), an area with sea surface temperature between 0.5 and $1 \mathrm{~K}$ below that of surrounding regions. The seven drifters moving along the Ridge follow roughly the same path parallel to the $100 \mathrm{~m}$ contour, but three are deflected across-contour toward the Fair Isle Channel on days 63 (7 July, 1996), 121 (7 September, 1996) and 159 (9 October, 1996), which are all days of high winds $\left(7.8,7.3\right.$ and $10.2 \mathrm{~m} \mathrm{~s}^{-1}$ respectively from $250^{\circ} \mathrm{N}, 210^{\circ} \mathrm{N}$ and $280^{\circ} \mathrm{N}$ ). Crossing the Orkney-Shetland Ridge drifters have speeds of 0.17 $\mathrm{m} \mathrm{s}^{-1}, 0.05 \mathrm{~m} \mathrm{~s}^{-1}$ and $0.15 \mathrm{~m} \mathrm{~s}^{-1}$, and encounter a further decrease of $0.5 \mathrm{~K}$ in sea-surface temperature. The Fair Isle Current carries drifters into the northern North Sea in a cyclonic circulation around the western flank of the Fladden Ground. During the same period three drifters are carried around the north of the Shetland Isles and enter the East Shetland Current. Their path traverses an area of reduced sea-surface temperature, $0.5 \mathrm{~K}$ below neighbouring regions to the north of Shetland, on days 71 (14 July, 1996) and 146 (26 September, 1996) under winds of $10 \mathrm{~m} \mathrm{~s}^{-1}$ at $260^{\circ} \mathrm{N}$ and $10 \mathrm{~m} \mathrm{~s}^{-1} 210^{\circ} \mathrm{N}$. Entering the East Shetland current 5-10 days later, they are advected southward at about $0.3 \mathrm{~m} \mathrm{~s}^{-1}$, along the eastern coast of Shetland, where the bathymetry rapidly deepens. The two drifters entering the Shetland Current on 26 September, 1996 are advected out of the current after 2-3 days when the high winds turn to $330^{\circ} \mathrm{N}$. These drifters move toward the northeast for 15 days, and having by this time moved $100 \mathrm{~km}$ to the east of Shetland, then turn southward and are carried rapidly (at about $0.3 \mathrm{~m} \mathrm{~s}^{-1}$ ) 


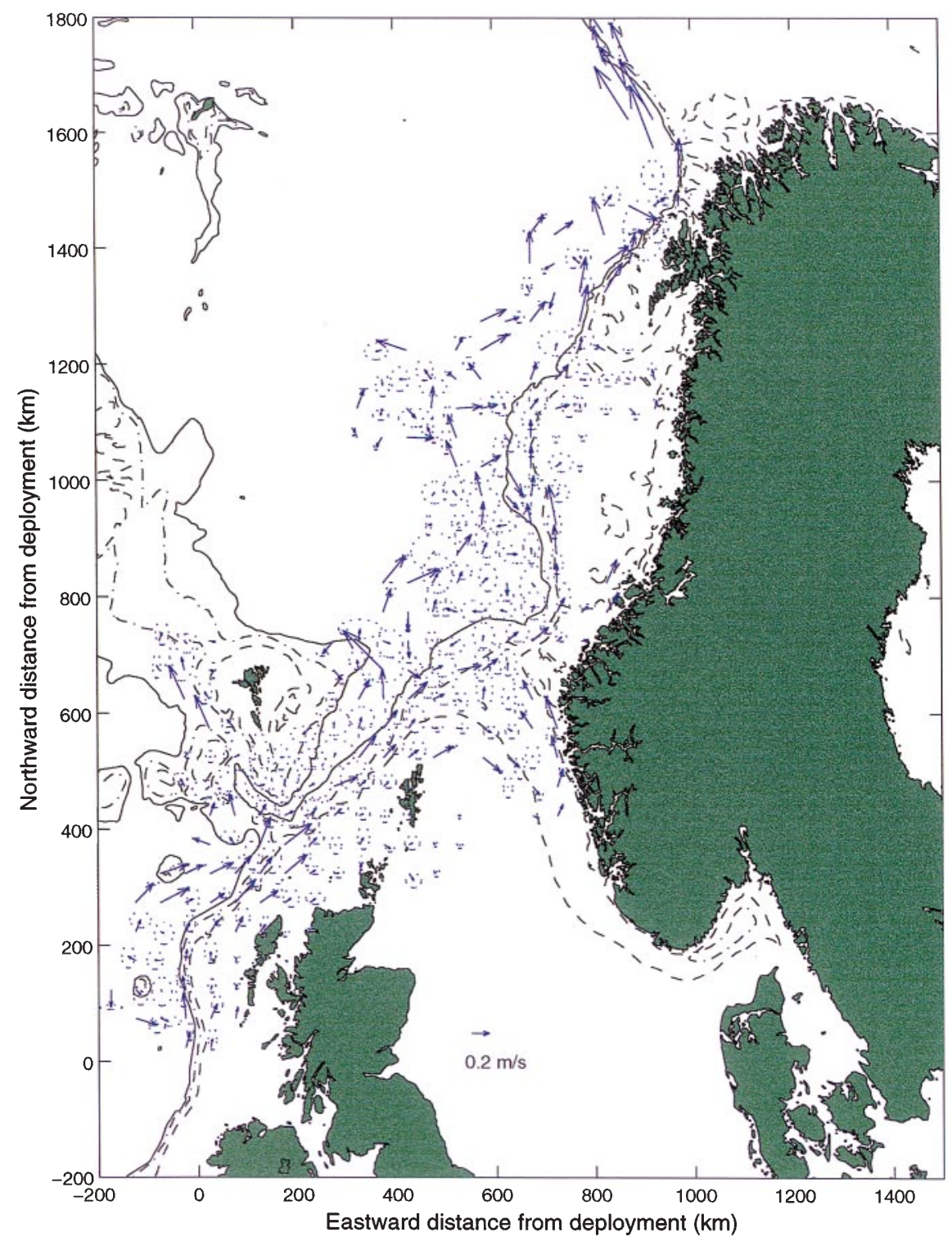

Fig. 7. Spatially averaged current vectors with associated first standard deviations in the point ellipse. Averages are made in $50 \mathrm{~km}$ boxes on Cartesian (north and east) axes through 180 days after the winter deployment into the North Sea, where they circulate cyclonically around the Fladden Ground.

Two winter drifters travel through the Fair Isle Channel (28 February, 1996) without any measurable local decrease in SST, at speeds are comparable to those in summer. They stagnate for 55 days to the south of the Shetland Isles after crossing the Ridge. Having subsequently passed into the North Sea one drifter meanders intermittently across the Fladden Ground.

\section{Scales of variation}

\subsection{Velocity products}

The correlation products $\left\langle u^{\prime} u^{\prime}\right\rangle,\left\langle v^{\prime} v^{\prime}\right\rangle$ and $\left\langle u^{\prime} v^{\prime}\right\rangle$, are calculated by averaging current variations from the mean velocity profiles of Fig. 5 in $25 \mathrm{~km}$ across-slope bins, i.e. strips $25 \mathrm{~km}$ wide oriented parallel to the $500 \mathrm{~m}$ contour. Figure 10 shows the results for summer and winter adjacent to the Hebrides and Shetland slopes with averages taken over the initial 100 days of each deployment.

The product, $\left\langle u^{\prime} v^{\prime}\right\rangle$, consistently has a minimum at the $500 \mathrm{~m}$ contour indicating low levels of eddy fluxes in the slope current. It is uniform on the Hebrides Shelf (Fig. 10a) between the 20 and $80 \mathrm{~km}$ east of the slope, declining to zero at the Scottish coast during winter. During summer diminished surface forcing lead to lower stresses over the continental shelves (Fig. 10b, d). The Hebrides shelf is fairly isotropic, but with declining stress toward the coast (Fig. 10b). The Rockall Channel has its largest stresses over the region of mesoscale eddies attached to the Anton Dohrn Seamount and to the slope during summer (Fig. 10b). Reynolds stresses, $\left\langle u^{\prime} v^{\prime}\right\rangle$, are considerably larger in the Faeroe Shetland Channel, an area of vigorous eddies. Here $\left\langle v^{\prime} v^{\prime}\right\rangle$ has a maximum value of $0.05 \mathrm{~m}^{2} \mathrm{~s}^{-2}$ at $25 \mathrm{~km}$ oceanward of the slope and $\left\langle u^{\prime} v^{\prime}\right\rangle$ is also increased significantly. Throughout the seasons the Reynolds stresses are 


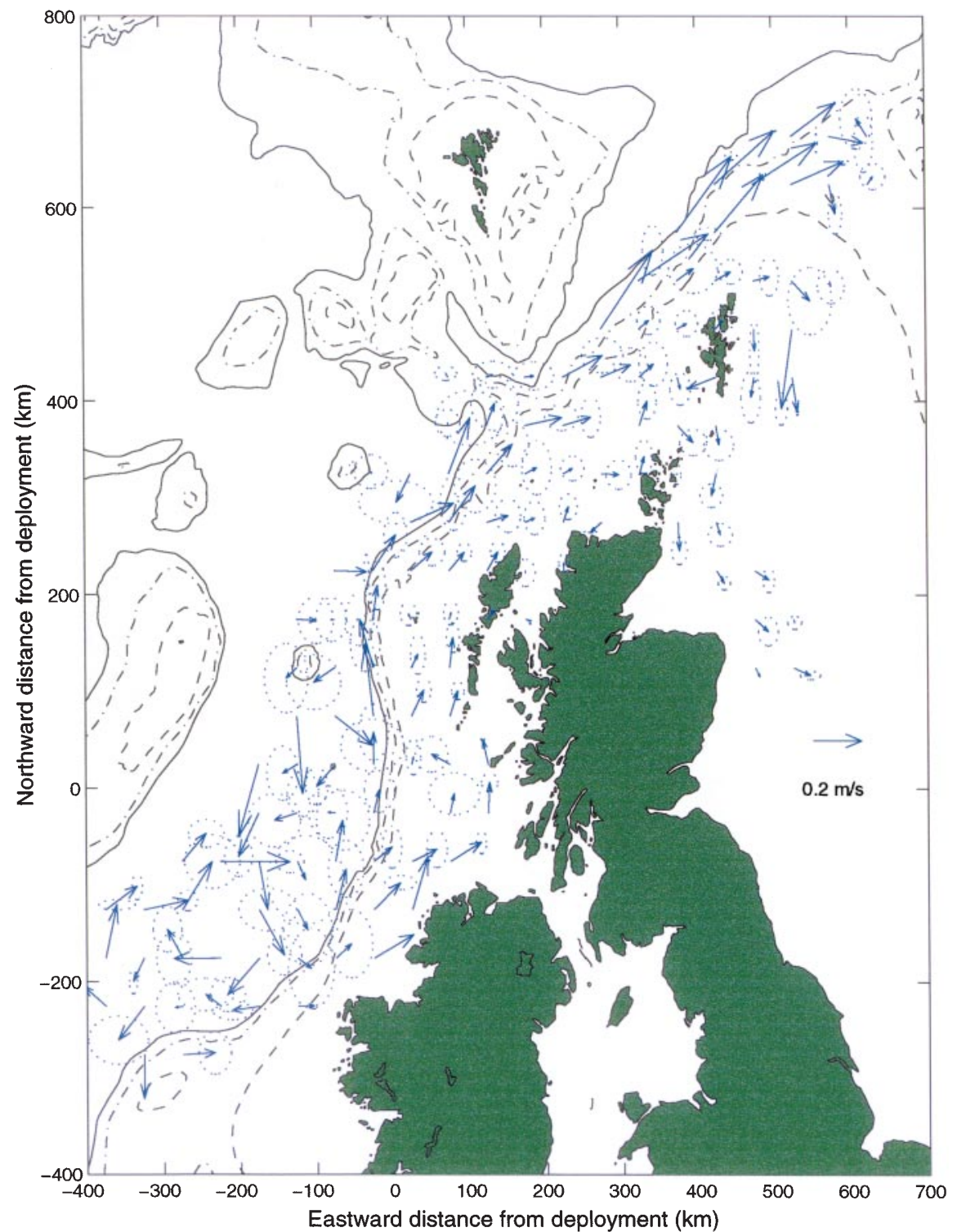

Fig. 8. Spatially averaged current vectors with associated first standard deviations in the point ellipse. Averages are made in $50 \mathrm{~km}$ boxes on Cartesian (north and east) axes during 180 days after the summer deployment consistently small relative to $\left\langle u^{\prime} u^{\prime}\right\rangle$ and $\left\langle v^{\prime} v^{\prime}\right\rangle$; along-and across-slope velocities are statistically independent, and no consistent direction is found for the eddy stresses.

\subsection{Temporal variations}

Following Booth (1988b) we use the Lagrangian temporal scale of velocity correlation to define the typical temporal extent of velocity variations and thereby the time between independent velocity estimates. The Lagrangian velocity correlation, $C(\tau)=$ $\left\langle u^{\prime}(t) u^{\prime}(t+\tau)\right\rangle / u^{\prime 2}$, where $u^{\prime}=u-\langle u\rangle$, where $\langle u\rangle$ is the Lagrangian mean velocity for each drifter and $\tau$ is a time lag. These product moment correlations of time lagged velocities are averaged in each season and region; the shelf, slope or deep water. The Lagrangian time scale, $\tau_{0}$, is defined as the first zero crossing in $C(\tau)$, and values are given in Table 1 . Where the time scales are very long e.g. in dominant mesoscale eddies, an alternative time scale defined where $C(\tau)$ is below 0.25 is given in brackets.

The correlation function found from drifters in the Rockall Channel is in close agreement with that found by Booth (1988b), and has the longest scale of correlation of the three regions. The shelf drifters were significantly correlated for 17 days in along-slope velocity during winter.

In calculating the statistical significance in the following sections a decorrelation time scale of 4 days has been adopted, after which the velocity estimates are supposed to be independent.

\subsection{Spatial variation}

The spatial scale of variability is measured by the average product moment correlation of spatially lagged Reynolds stresses. The Lagrangian correlation, $C(\xi)=\left\langle u^{\prime}(l) u^{\prime}(l+\xi)\right\rangle / u^{\prime 2}$, is the average correlation 


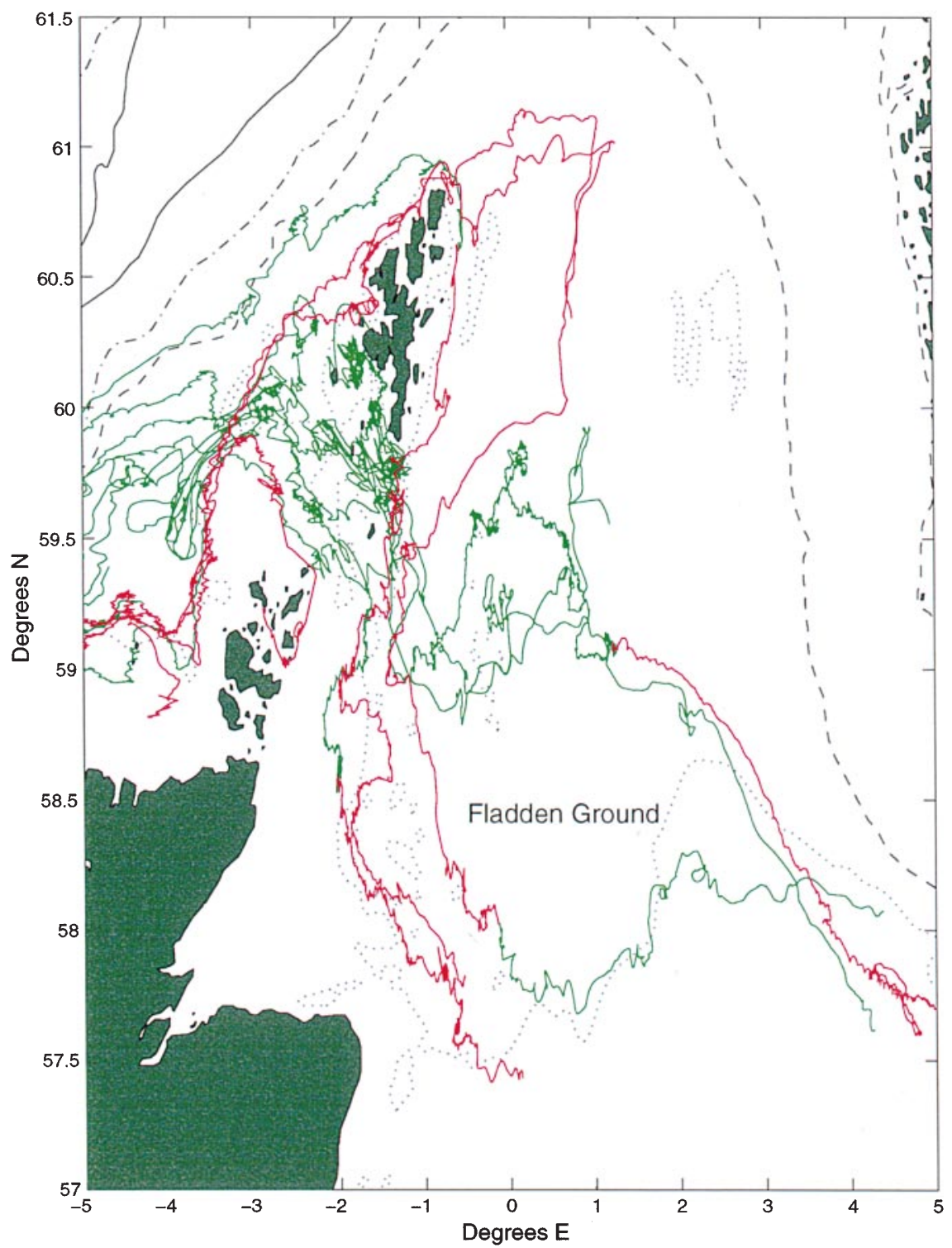

Fig. 9. Drifter tracks near the Fair Isle Channel, coloured by time of year in 1996 and 1997. Green indicates paths between 1 January and 1 August, 1996, and red otherwise. The general movement of drifters is from to west to the east coefficient of simultaneous velocities from drifter pairs that both lie over the slope, shelf or deep regions and are separated by a distance $\xi$, measured in $10 \mathrm{~km}$ bins. The distance to the second zero crossing in $C(\xi)$, defining the spatial correlation scale, $\xi_{0}$, where the drifters become fully decorrelated, are given in Table 2. Alternatively where there are no zero crossings the distance to the second minima has been used.

The correlation $C(\xi)$ is calculated for drifter pairs on the shelf, slope and in deep water over 100 days of both seasons. $\xi_{0}$ is determined by the constraining effect of the Scottish coastline which is roughly parallel to the shelf edge at the Hebrides Shelf, and the scale of the forcing. During winter and summer the shelf drifters do not become fully decorrelated in along-slope velocity over scales of $>200 \mathrm{~km}$, similar to the extent of weather systems over this region. Across-slope decorrelation occurred within much smaller scales, $60 \mathrm{~km}$ in winter and $30 \mathrm{~km}$ in summer. The slope current varies in velocity along its length on $60 \mathrm{~km}$ scales. The along and across-slope velocities of drifters in deep water were decorrelated within $30 \mathrm{~km}$ during both seasons.

\section{Dispersion}

\subsection{Direction}

Whilst the drifters remain in the region of the Hebrides slope the initial across-slope inter-circle distribution is maintained (Figs. 3a, 4a), in that drifters deployed in deep waters remain in deep waters, whilst those deployed over shallow waters disperse into shallow waters. The centroid of circle 2 drifters generally remain between that of the drifters of both circle 1 and circle 3 .

\subsection{Causes of dispersion}

6.2.1. Bathymetric. Oceanward transport of drifters from the slope current occurs in the lee of bathymetric 

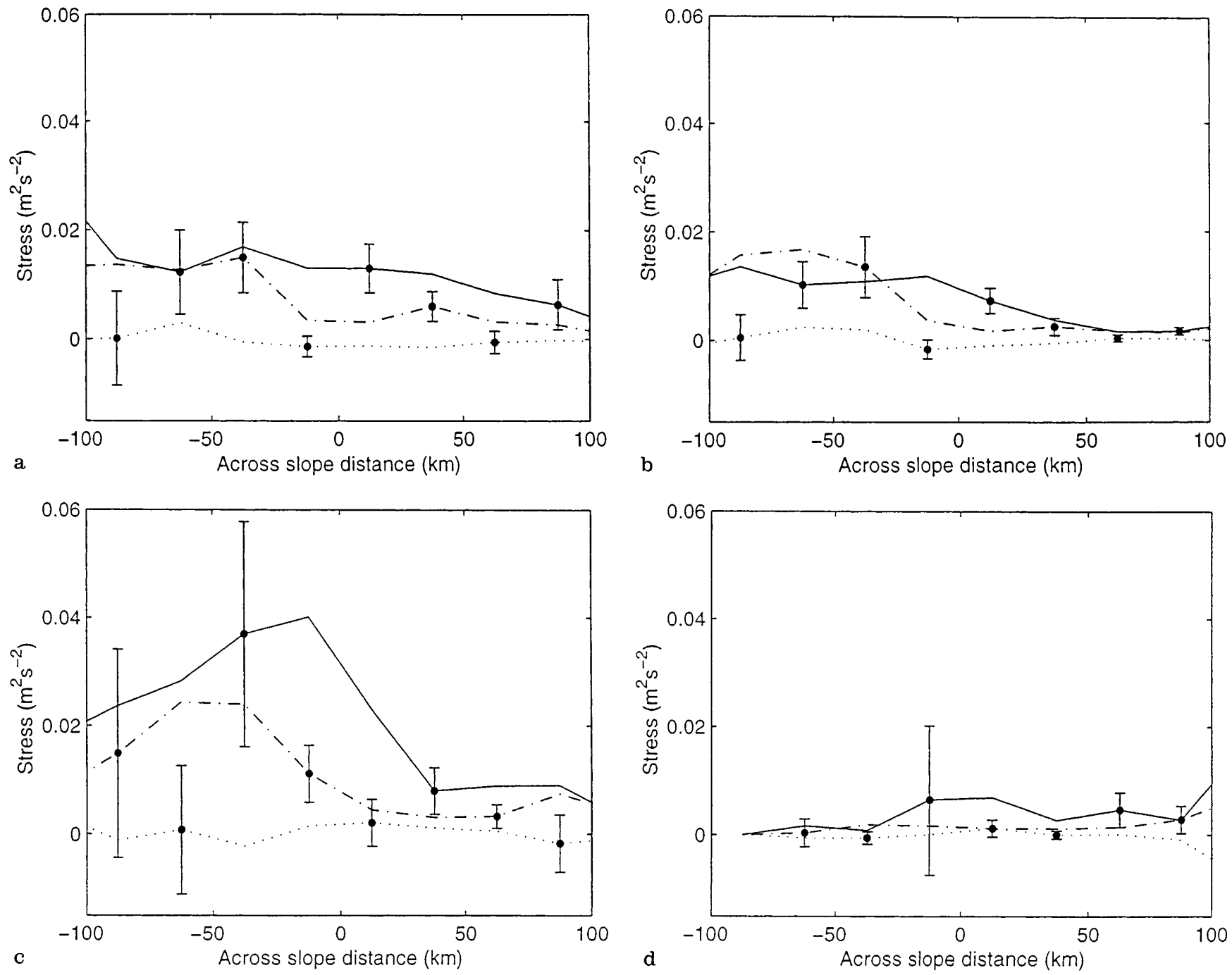

Fig 10a-d. $\left\langle u^{\prime} u^{\prime}\right\rangle$ (dot-dashed), $\left\langle v^{\prime} v^{\prime}\right\rangle \quad$ (solid) and $\left\langle u^{\prime} v^{\prime}\right\rangle \quad$ (dotted) calculated as spatially and temporally averaged deviations from the mean current. Profiles across the a Hebrides slope during winter,

irregularities, slope fans, seamounts and ridges. This is $(b, c)$ evident at the Barra Fan during summer, $\mathbf{C}$ in Fig. 4, the Anton Dohrn Seamount during both deployments identically, $\mathbf{B}$ in Figs. 3, 4, and to the northeast of the Wyville Thomson Ridge in winter (Fig. 11a). These are the only permanent areas of oceanward movement adjacent to the Hebrides and East Shetland Shelves.

Table 1. Lagrangian correlation time scales, as the first zero crossing $\tau_{0}$ in $C(\tau)$, the Lagrangian velocity correlation time scale

\begin{tabular}{llllll}
\hline & \multicolumn{2}{l}{ Along-slope, $\tau_{0}$ (days) } & & \multicolumn{2}{l}{ Across-slope, $\tau_{0}$ (days) } \\
\cline { 2 - 3 } \cline { 6 - 6 } \cline { 5 - 6 } & Winter & Summer & & Winter & Summer \\
\hline Shelf & $17(3)$ & 3 & & 2 & 2 \\
Slope & 2 & 3 & & 1 & 2 \\
Deep & $90(15)$ & $80(21)$ & & $21(6)$ & $34(12)$ \\
\hline
\end{tabular}

b Hebrides slope during summer, c Shetland slope during winter and d Shetland slope during summer. Error bars show the confidence in the mean

The relative importance of these is measured by the number of drifters detrained. The Barra fan flow draws 4 of the 7 circle 3 in summer (Fig. 11b). These 4 drifters are rapidly separated in a southward flow, then become entrained in a persistent cyclonic eddy adjacent to the slope (Fig. 4c, d). The Anton Dohrn Seamount causes a bifurcation in the flow which carries 4 winter drifters (see Fig. 11c), and 3 summer drifters (see Fig. 11d), into

Table 2. Lagrangian correlation length scales, $\xi_{0}$, calculated as the second zero crossing in $C(\xi)$, or where there are no zero crossings, as the second minima in $C(\xi)$.

\begin{tabular}{llllll}
\hline & \multicolumn{2}{l}{ Along-slope, $\xi_{0}(\mathrm{~km})$} & & \multicolumn{2}{l}{ Across-slope, $\xi_{0}(\mathrm{~km})$} \\
\cline { 2 - 3 } \cline { 6 - 6 } \cline { 5 - 6 } & Winter & Summer & & Winter & Summer \\
\hline Shelf & $>200$ & $>200$ & & 60 & 30 \\
Slope & 60 & 60 & & - & - \\
Deep & 30 & 30 & & 30 & 30 \\
\hline
\end{tabular}


the Rockall Channel in an intense (peak speed of 0.3 $\mathrm{m} \mathrm{s}^{-1}$ ) and laterally confined $(5-15 \mathrm{~km}$ wide) flow. During the winter these drifters are drawn into an anticyclonic eddy to the north of the seamount, and a cyclonic eddy overlying the seamount. The summer drifters that are detrained from the slope current were drawn into similar dipolar eddies. There is evidence however from drifters re-seeded into the slope current south of the Anton Dohrn Seamount that the flow deflected to the west in the bifurcation region varies in direction and strength throughout the year, and in its interaction with the seamount eddies.

In contrast, dispersion onto the shelf is not associated with bathymetric irregularities. During winter movement of drifters across the shelf break occurred uniformly between $56.5^{\circ}$ and $57.75^{\circ} \mathrm{N}$ for drifters east of the $500 \mathrm{~m}$ contour (Fig. 11e). Seven drifters are carried over the shelf break in a perturbation of the whole jet. These drifters move eastward dispersing across over half of the shelf width within 10 days. Subsequent cross shelf break flows carry shelfward drifters intermittently into the slow northward shelf current.

After deployment the summer circle 1 drifters are trapped in a gently oscillating shelf break stagnation zone (Fig. 11f). Movement is confined to $60 \mathrm{~km}$ alongslope and $35 \mathrm{~km}$ across-slope and is non-dispersive and oscillatory to day 22 . A strong south-southwesterly wind subsequently advected these drifters into the dispersive and slow shelf flows (Fig. 4b).

6.2.2 Meteorological. During high winds drifters converge onto the slope (e.g. Fig. 3b). This is particularly evident during the high winds of days 25-40 and 75-85 of the winter deployment. The first high wind (Sect. 3.3) causes the mean separation of drifters around the shelf break to fall from $60 \mathrm{~km}$ to $40 \mathrm{~km}$ (Fig. 13c), equivalent to a dispersion coefficient in the $X$-direction, $K_{X}=-700 \mathrm{~m}^{2} \mathrm{~s}^{-1}$ using the dispersion rates described later in sect. 6.3. Similarly the $13 \pm 5 \mathrm{~m} \mathrm{~s}^{-1}$ winds oriented between $210^{\circ}$ and $90^{\circ}$ between days 75 and 85 cause a reduction in the mean separation of drifters from $75 \mathrm{~km}$ to $55 \mathrm{~km}$ (corresponding to a rate of $K_{X}=-2500 \mathrm{~m}^{2} \mathrm{~s}^{-1}$ ), a rapid event compared with the average rate of dispersion (see also Fig. 13c and discussion in Sect. 6.3.1). These periods of negative $X$ dispersion are however accompanied by positive $Y$ dispersion, as expected in a horizontal, non-divergent flow. No similar patterns of convergence are associated with the equally high winds during summer.

\subsection{Rates}

6.3.1 Temporal. The velocity shear associated with the slope current (Sect. 3.1) dominates the along-slope dispersion of drifters near the slope. Dispersion in the Rockall Channel is greater than that on the shelf; the larger scale redistribution of drifters through the action of mesoscale eddies exposes the drifters to a greater velocity shear and larger scale transport.
Simultaneous drifter position are segregated into bins of $10 \mathrm{~km}$ in along and across-slope distance and $1 / 2$ days from deployment. The distribution of drifters in the two-dimensional boxes with time is shown in Fig. 12 (a, $\mathrm{c}$ across-slope, and $\mathrm{b}, \mathrm{d}$ along-slope). Mean position, variance in position, and skewness time series have been calculated for both arrays over the initial 100 days, and are illustrated in Figs. 13 and 14. The rate of spreading in the particle cloud is described by coefficients of dispersion, $K_{X}=(1 / 2) \mathrm{d} \sigma_{X} / \mathrm{d} t$ and $K_{Y}=(1 / 2) \mathrm{d} \sigma_{Y} / \mathrm{d} t$, where $\sigma_{X}$ and $\sigma_{Y}$ are the variances of drifter positions in the across-slope and along-slope directions respectively. Linear regressions for dispersion coefficients $K_{Y}, K_{X}$ have been taken from the variance of drifter position calculated for the 100 days shown in Fig. 12, and are tabulated in Table 3.

The dispersion coefficients are approximately proportional to $t^{p}$. In the across-slope $(X)$ direction $p$ has a value in winter of 1.3 between day 1 and day 17 , afterwards decreasing to about 0.25. During summer, $\mathrm{p}$ is about 2 for across-slope dispersion over the initial 10 days, but decreases to 0.25 after day 45 . For along-slope $(Y)$ dispersion, $p$ is about 2 between days 3 and 30 , decreasing thereafter to 0.25 during both winter and summer.

The skewness of the drifter positions (Figs. 13, 14) in the across-slope $(X)$ direction lies between -0.5 and 0.5 during the initial 50 days of winter. However during summer outliers were oceanward giving persistently negative skewness near -0.5 . The along-slope skewness $(Y)$ is positive and linearly increasing during the first days of summer when the combination of limited acrossslope dispersion and high slope current velocity shear leads to a higher outlier density at large along-slope distances.

There are appreciable and significant differences in the rates of dispersion of the separate circles. Circle 2 drifters dispersed slowly during winter (see Fig. 12a, b), with $K_{Y}=1.6 K_{X} \approx 700 \mathrm{~m}^{2} \mathrm{~s}^{-1}$ in the slope current. The slope is also relatively non-dispersive through the initial 30 days of the summer deployment. Subsequently however circle 2 drifters were rapidly separated as the slope region is completely denuded (principally by drifters moving toward the shelf). This easterly movement from the slope was concurrent with $200 \pm 30^{\circ} \mathrm{N}$ winds of speed $13 \mathrm{~m} \mathrm{~s}^{-1}$.

In deeper waters, dispersion is dominated by largescale $(50-200 \mathrm{~km})$ eddies (see Figs. 3, 4). Dispersion is greatest here during both seasons. These eddies are most evident during summer when they cause the oscillation in the variance after day 20 (Fig. 14c). Westward dispersion is limited; no drifters are transported beyond $150 \mathrm{~km}$ from the slope, half the overall width of the Rockall Channel.

Circle 1 drifters disperse over the entire shelf at a rate intermediate between those in deep water and those over the slope. During winter the most rapid dispersion is in the initial 15 days. Reversals in the shelf current are particularly important in spreading the drifters on the shelf. There are also periods of stagnation. The shelf was much less dispersive during summer. The drifters being 

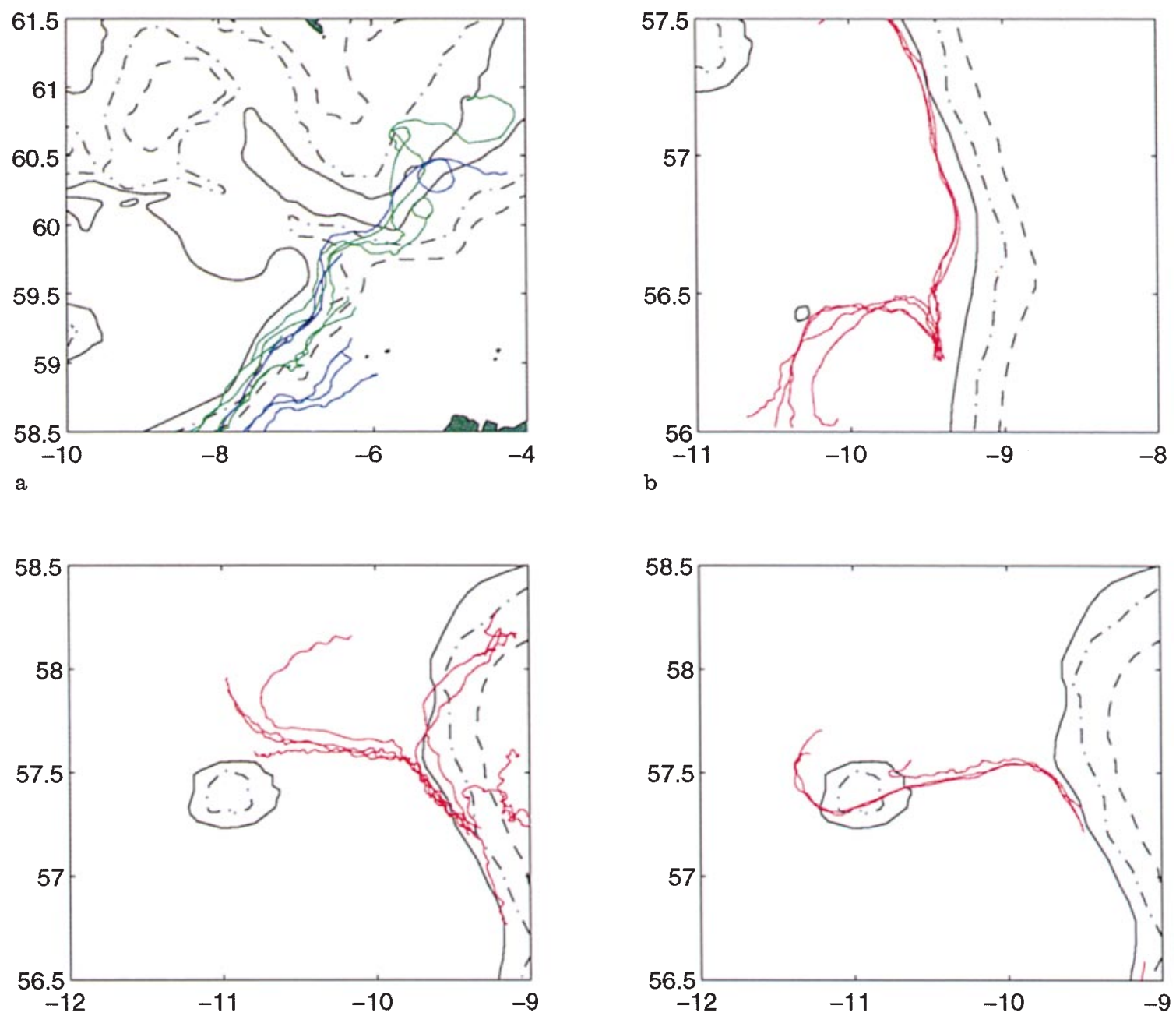

c
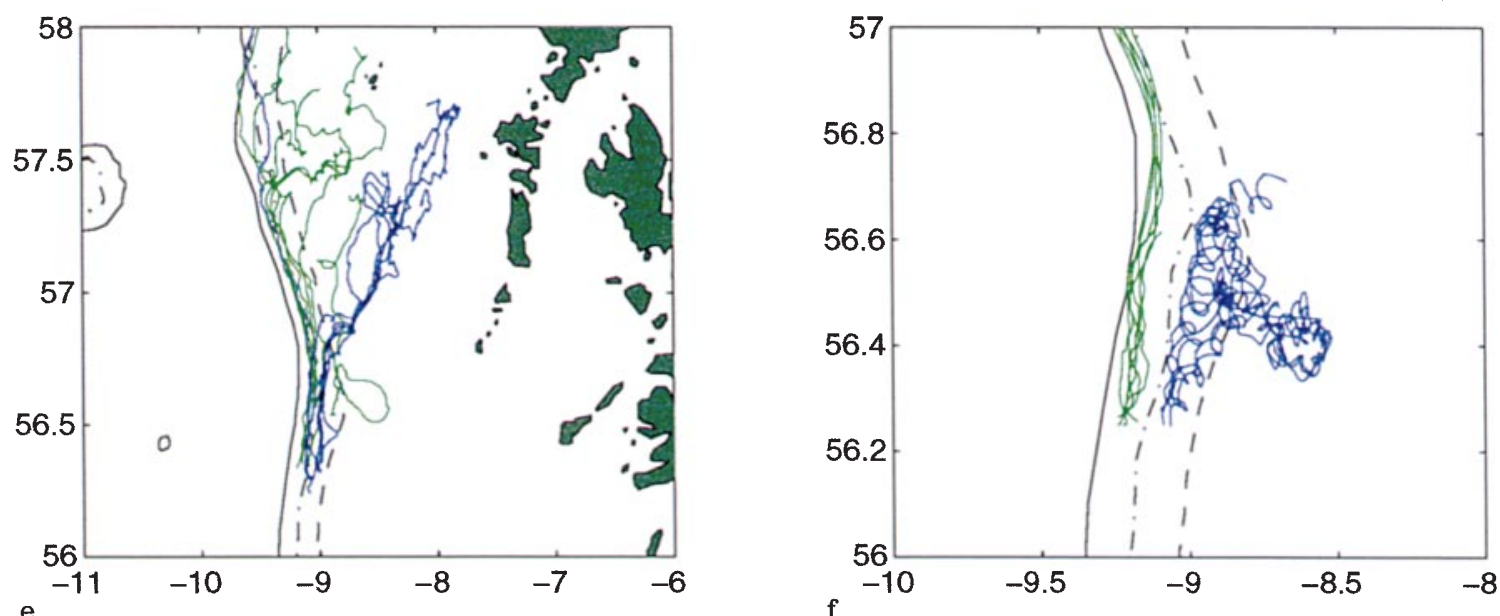

Fig. 11a-f. Dispersive events from the slope current during winter in the left column (a, c, e) and summer in the right (b, d, f). The deployment circles are coloured as in Figs. 3-4. a All winter drifters through days 25-35 near the Wyville Thomson Ridge, where the drifters are deflected into the Faeroe-Shetland Channel. b Circle 3 summer drifters immediately after deployment, four drifters enter a southward drifting cyclonic eddy at the Barra Fan. c, d Show the

nearly identical winter and summer bifurcations in the slope current adjacent to the Anton Dohrn Seamount, between days 8-18 after deployment. e, f Are shelfward dispersions. e Is the continuous dispersion of circle 1 and 2 drifters from east of the $500 \mathrm{~m}$ contour during the first 15 days of the winter deployment compared with $\mathbf{f}$ the stagnation of circle 1 drifters during the first 22 days of the summer deployment 

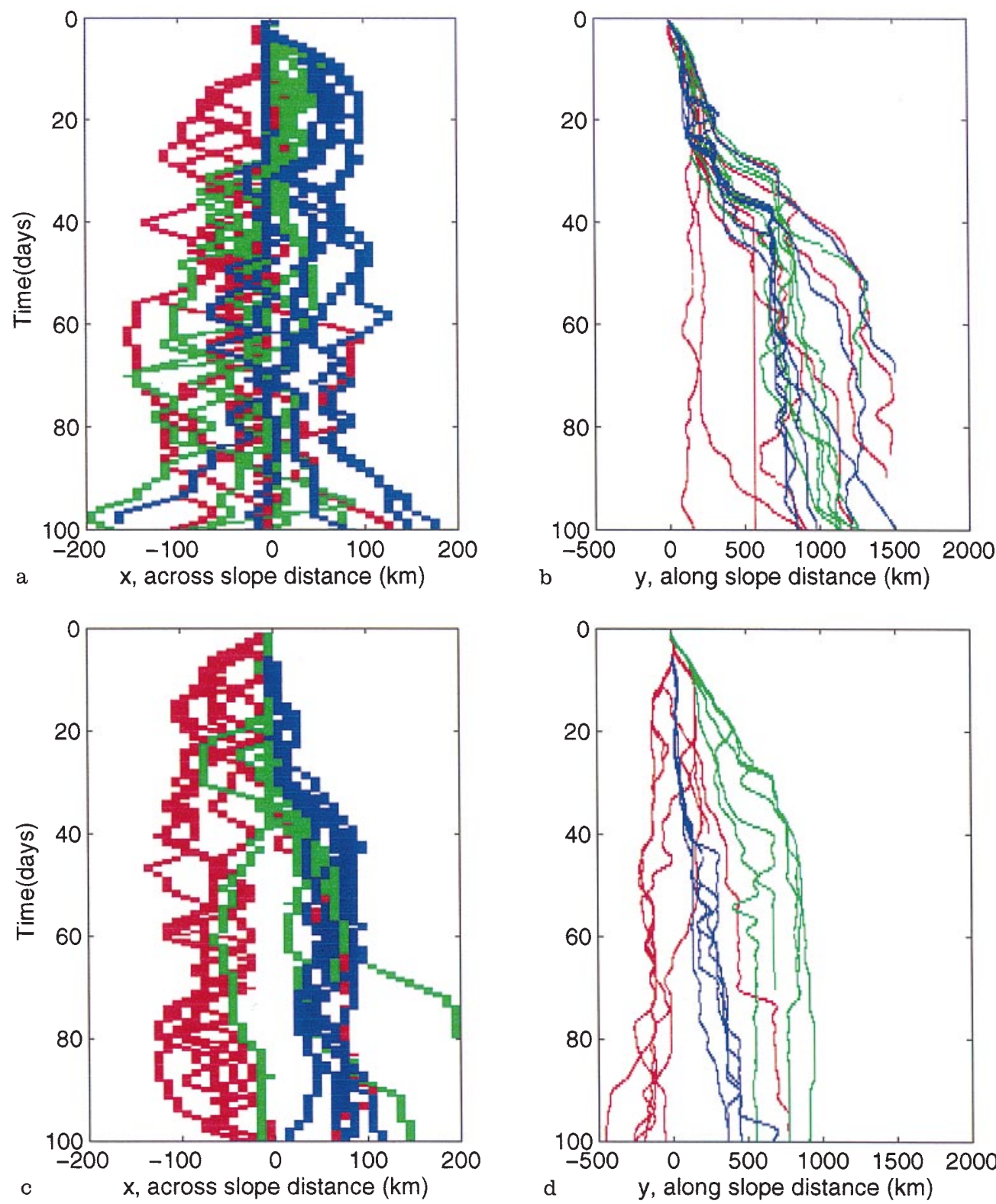

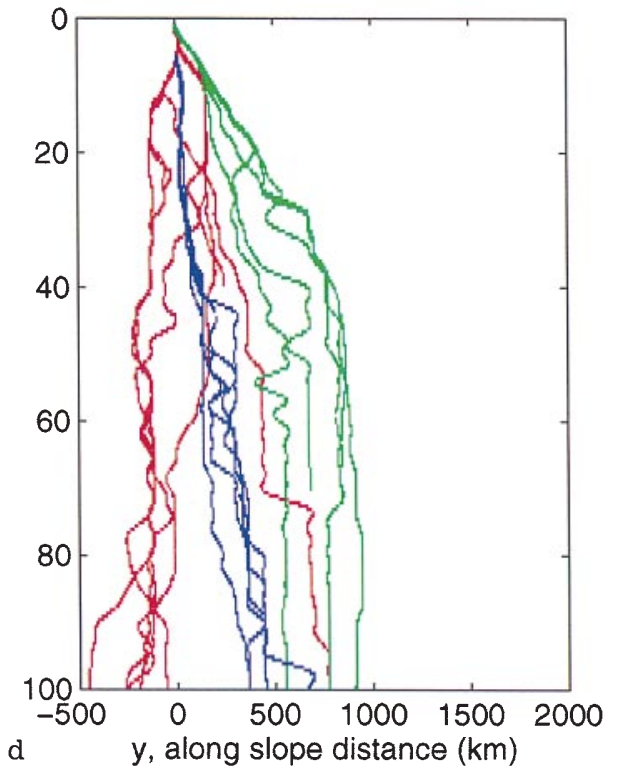

Fig. 12a-d. Distribution of a, b winter and $\mathbf{c}, \mathbf{d}$ summer drifters through the initial 100 days after deployment a, c across-slope, $\mathbf{b}, \mathbf{d}$ along-slope, in $10 \mathrm{~km}$ bins calculated at $1 / 2$ day periods. The three circles are coloured as in Fig. 3. In $\mathbf{b}$ the solid bar at $522 \mathrm{~km}$ along-slope after day 40 is the consequence of a stagnating drifter over the Faeroe Bank (522 $\mathrm{km}$ being the along-slope distance of the Wyville Thomson Ridge from the release position). Between days 40 and 100 of the summer release the slope region was completely denuded of drifters initially caught in the near-stagnation zone (Fig. 11f and Sect. 6.2.1), from which they only escape eastward during the high winds on day 22.

6.3.2 Scale of dispersion. Along and across-slope dispersion rates vary with along and across-slope length scales (i.e. array spread) for the three drifter groups. Dispersion rates and scales are calculated using the data of Fig. 12, where drifter concentrations are calculated in periods of half a day and in $10 \mathrm{~km}$ boxes across and along-slope. Least squares regression was used to calculate the powers in $K_{X, Y} \propto l^{p}$, where, following Okubo (1971), $l=6 \sigma_{X, Y}{ }^{2}$ is the scale of the dispersing array in which $\sigma_{X, Y}$ are the across and along-slope standard deviation of position. The mean 100-day powers, $p=\alpha_{X}$ and $\alpha_{Y}$, are tabulated in Table 3 for the three initial position circles.
During winter the 100 day average dispersion $K_{Y} \propto$ $l^{1.15 \pm 0.16}$, with weaker dispersion across the slope current, $K_{X} \propto l^{0.67 \pm 0.15}$. Evidence that the scale of dispersion is limited during the 100 days to the size of the Rockall Channel and shelf can be seen in Fig. 12a, c.

Fig. 13a-f. Summary statistics describing dispersion during winter along the two axes; $X$ across-slope distance from the $500 \mathrm{~m}$ contour, and $Y$ along-slope distance from deployment. a, b Show mean position $\mathrm{X}$ and $\mathrm{Y}$, respectively (with confidence limits indicated by the dash-dot lines), $\mathbf{c}, \mathbf{d}$ variance in $X$ and $Y$ position and e, $\mathbf{f}$ skewness are calculated. The solid bars in $\mathbf{a}, \mathbf{b}, \mathbf{c}$ bound the two periods of high winds, days 25-40 and days 75-85, when drifters converge on the $500 \mathrm{~m}$ contour whilst being advected along-slope more rapidly. The fitted straight lines in variance versus time (dot-dashed lines) in parts $\mathbf{c}$ and $\mathbf{d}$ correspond to an average dispersion rate of $8.8 \times 10^{3} \mathrm{~m}^{2} \mathrm{~s}^{-1}$ along-slope and $0.35 \times 10^{3} \mathrm{~m}^{2} \mathrm{~s}^{-1}$ across-slope 

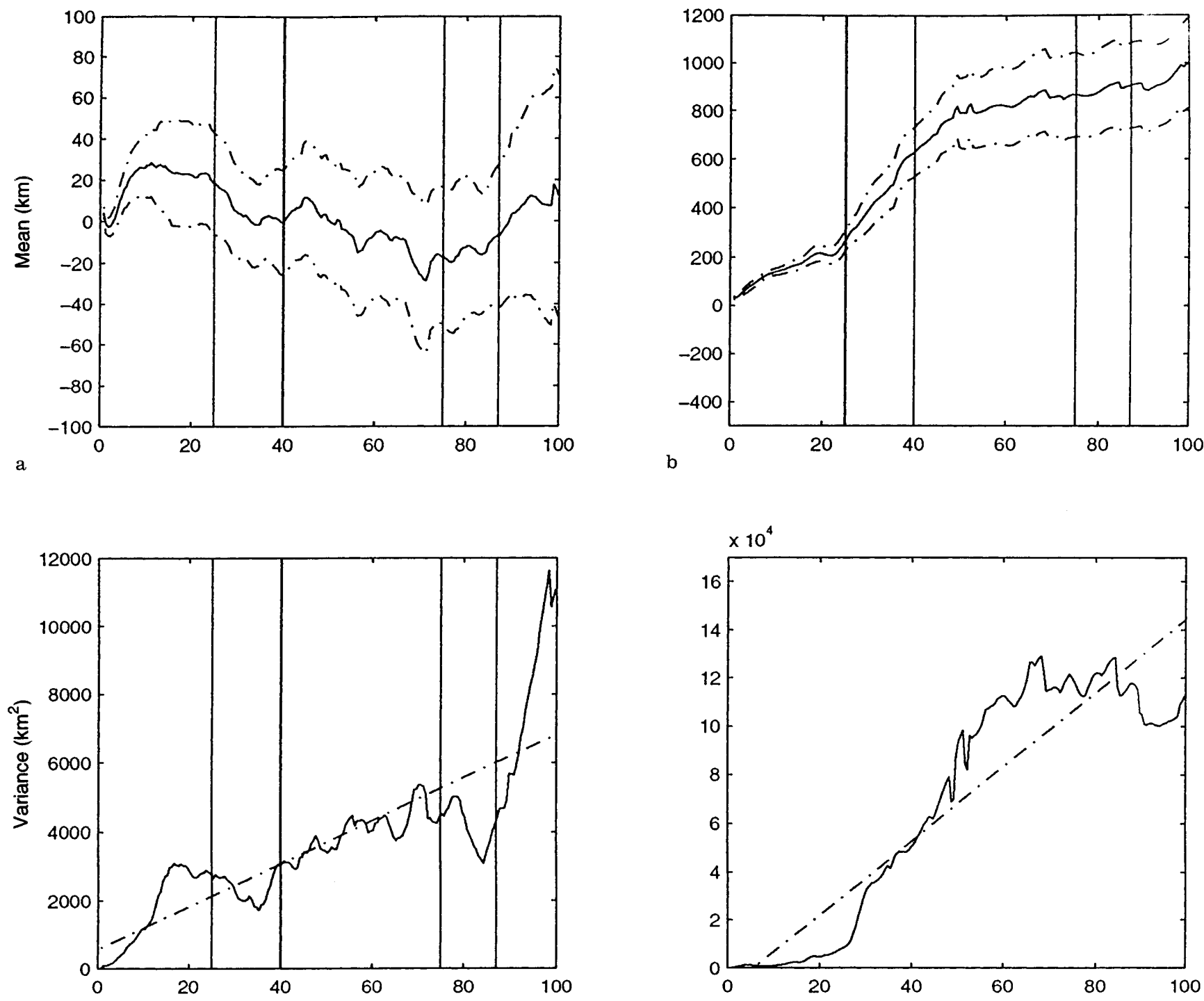

c

d
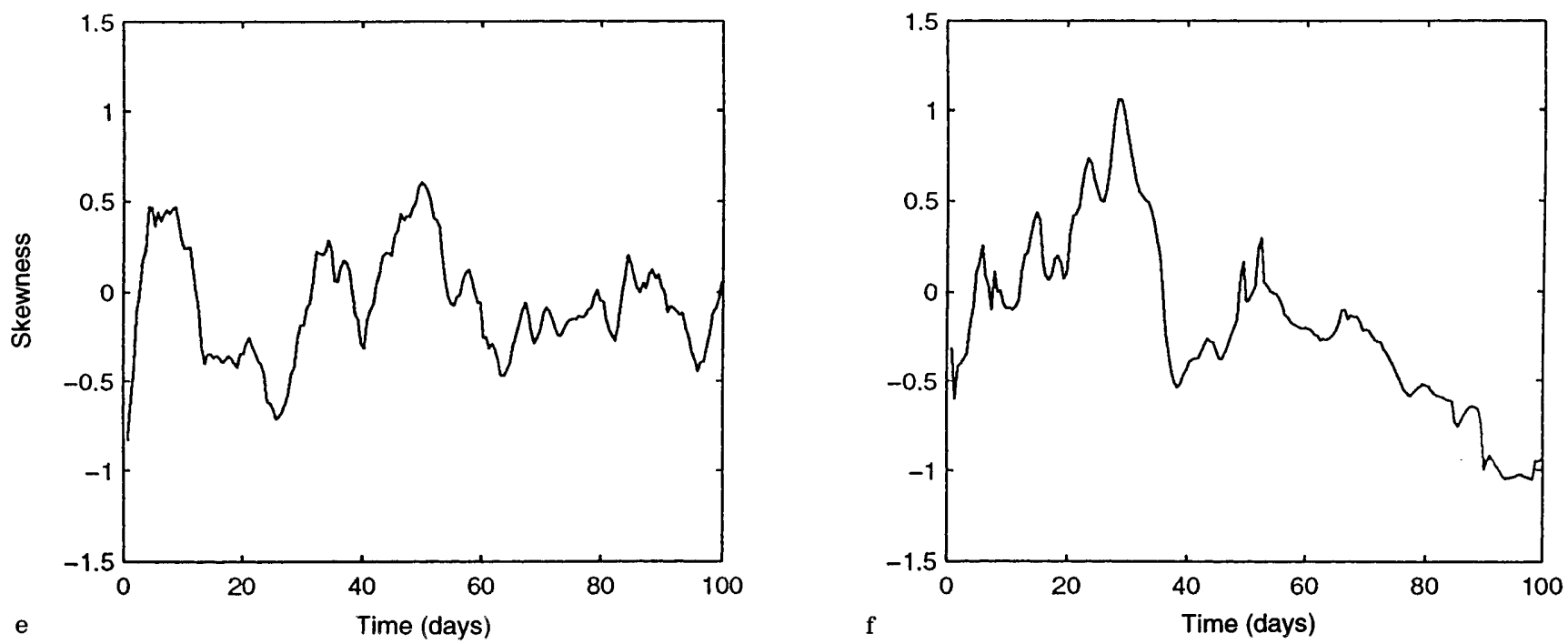

Fig. 13a-f. 


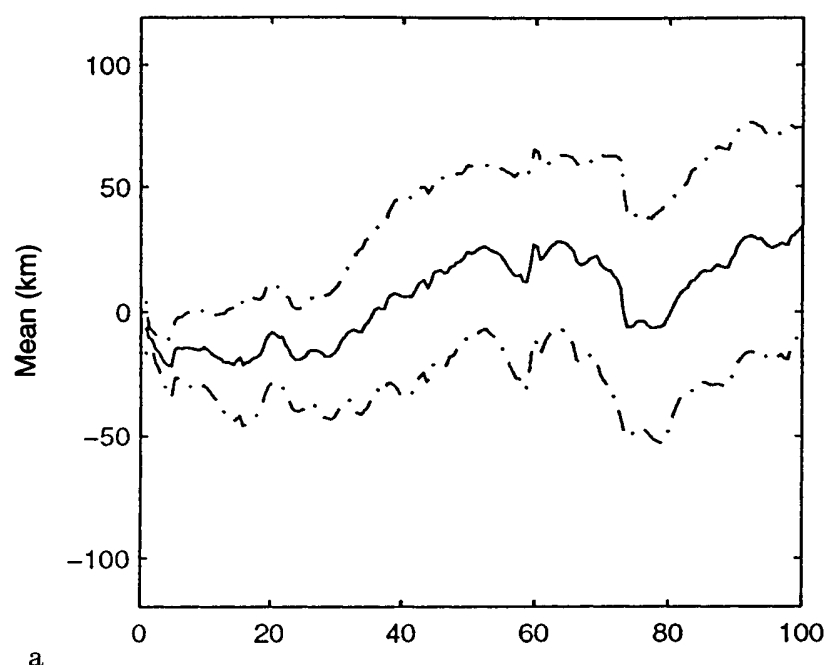

a
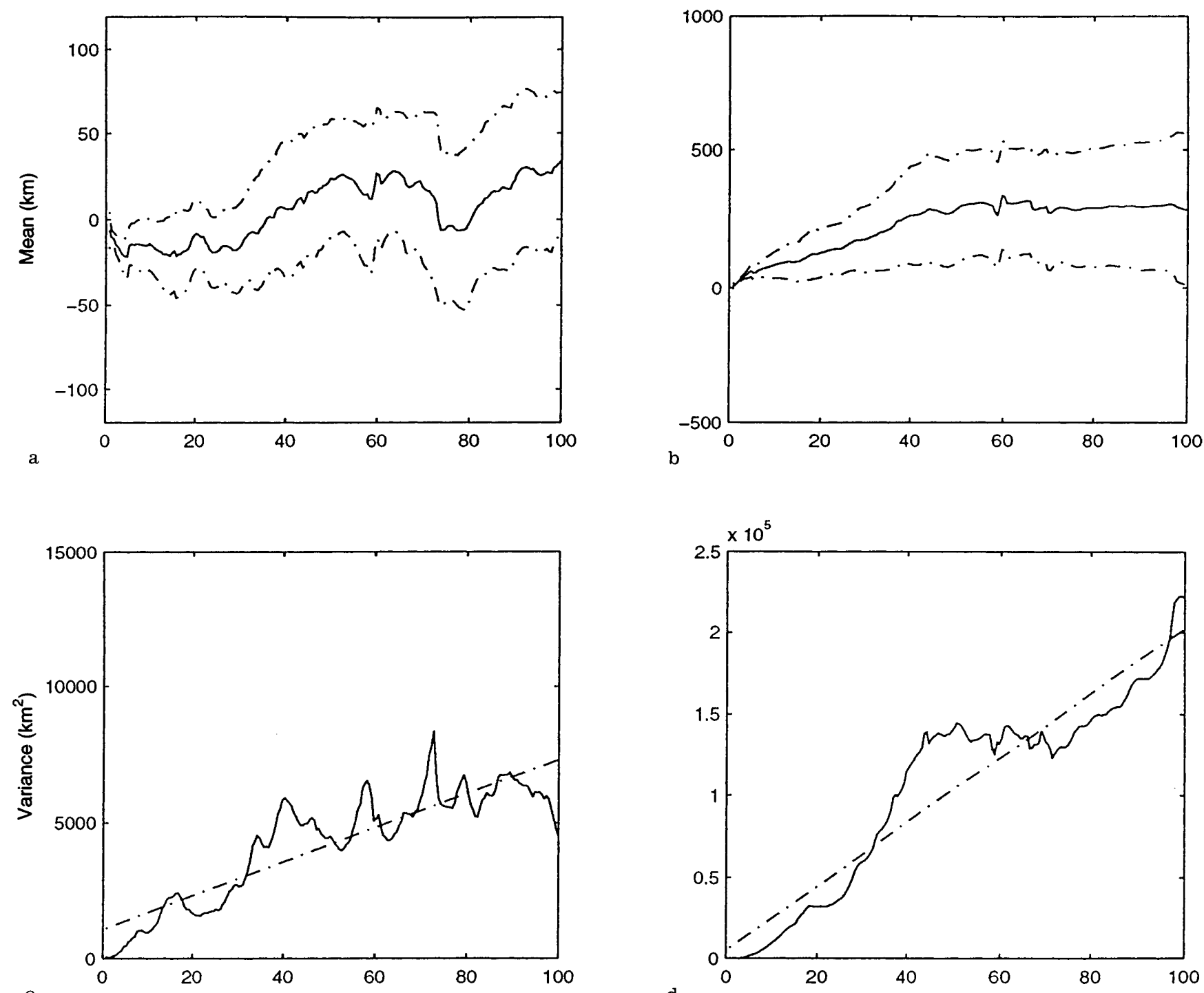

c

100

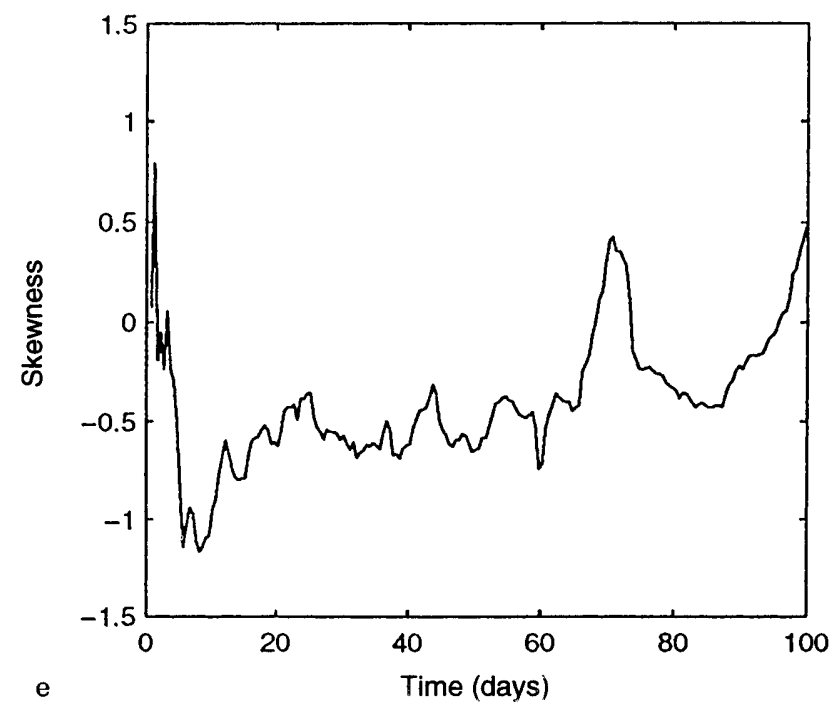

Fig. 14a-f. Summary statistics describing dispersion during summer along the two axes; $X$ across-slope distance from the $500 \mathrm{~m}$ contour, and $Y$ along-slope distance from deployment, as in Fig. 13. a, b Mean
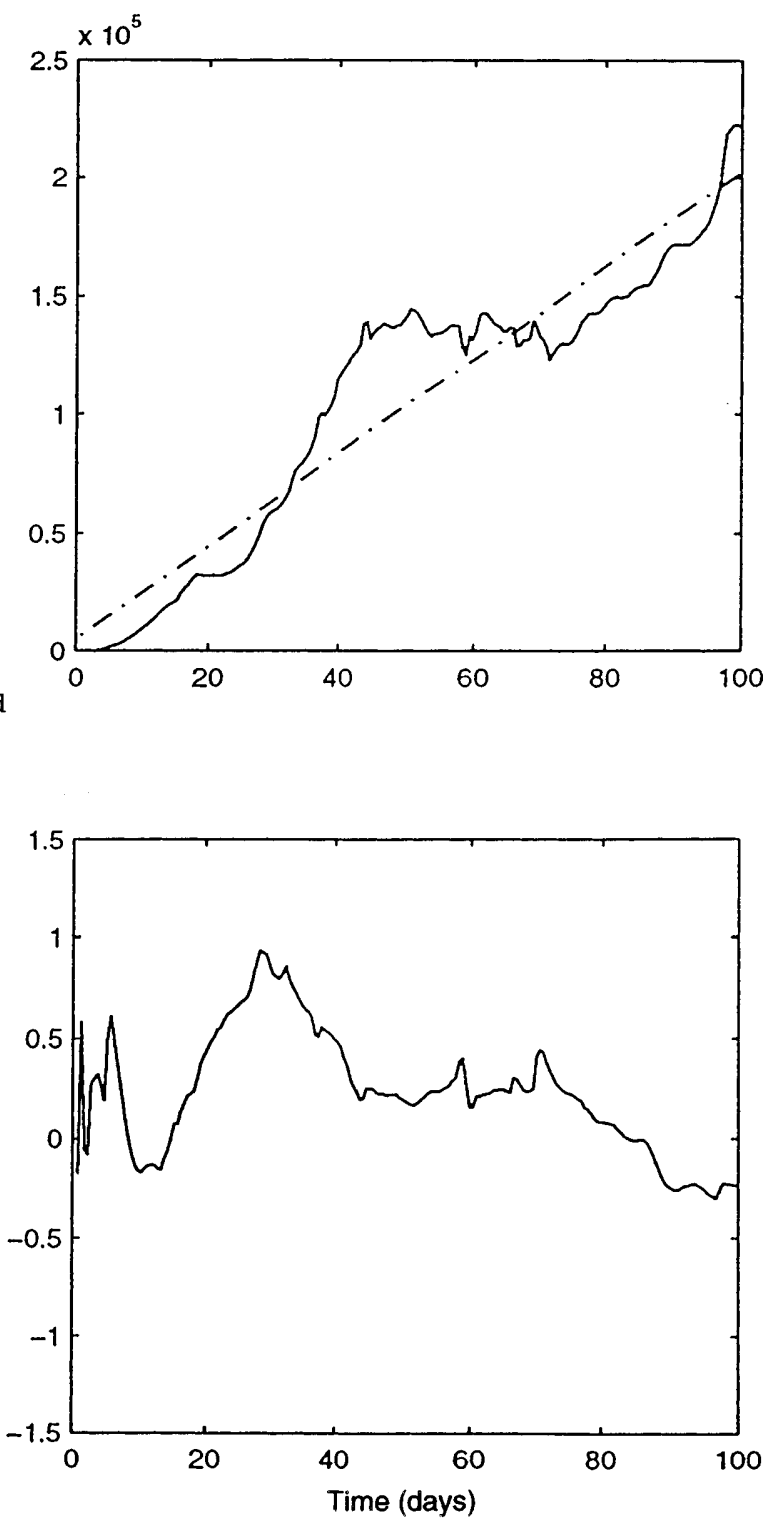

position $X$ and $Y$ respectively, $\mathbf{c}, \mathbf{d}$ variance in position and $\mathbf{e , ~} \mathbf{f}$ skewness of position 
Table 3. Mean 100-day dispersion coefficients for the dispersing drifter circles. $K_{X}$ and $K_{Y}$ are calculated from the rate of change in the variance of across and along-slope position, $X$ and $Y$. The regressed powers, $\alpha_{X}$ and $\alpha_{Y}$, are found from $K_{X, Y} \propto l^{p}$, where $p=\alpha_{X}$ and $\alpha_{Y}$ (see Sect. 6.3.1). The mean values of all three circles are given in the rows labelled winter and summer

\begin{tabular}{llrlll}
\hline & $\begin{array}{l}K_{X} \\
{\left[\mathrm{~m}^{2} \mathrm{~s}^{-1}\right]}\end{array}$ & $\begin{array}{c}K_{Y} \\
{\left[\mathrm{~m}^{2} \mathrm{~s}^{-1}\right]}\end{array}$ & $\begin{array}{l}\alpha_{X} \\
\text { Across }\end{array}$ & $\begin{array}{l}\alpha_{Y} \\
\text { Along }\end{array}$ & $\begin{array}{l}\text { Along-slope } \\
\text { velocity shear } \\
{\left[\times 10^{-6} \mathrm{~s}^{-1}\right]}\end{array}$ \\
\hline Winter & 360 & 8840 & & & 8 \\
Circle 1 & 490 & 4780 & 0.63 & 1.01 & \\
Circle 2 & 450 & 710 & 0.85 & 1.11 & \\
Circle 3 & 280 & 16850 & 0.54 & 1.33 & \\
Summer & 360 & 11380 & & & 9 \\
Circle 1 & 35 & 600 & 0.96 & 1.44 & \\
Circle 2 & 720 & 2170 & 1.39 & 1.14 & \\
Circle 3 & 360 & 9900 & 0.02 & 1.07 & \\
\hline
\end{tabular}

The deep water drifters are trapped in eddies. Initial across-slope dispersion increases slightly more rapidly $\left(K_{X} \propto l^{1.11 \pm 0.07}\right)$ than the along-slope $\left(K_{Y} \propto l^{1.01 \pm 0.1}\right)$. The quoted standard-deviation is the measured differences of the three circles in each deployment.

During summer there is a near linear increase in dispersion coefficient with scale, $K_{X} \propto \ell^{0.89 \pm 0.07}, K_{Y} \propto$ $l^{1.21 \pm 0.19}$. Initially the shear zone of the slope current causes dispersion to grow more rapidly with scale $\left(K_{X} \propto\right.$ $l^{1.49 \pm 0.70}$, and $K_{Y} \propto l^{1.31 \pm 0.38}$ to a distance $l=300 \mathrm{~km}$ ). This vigorous dispersion is followed for the initial 10 days, after which the shelf and ocean drifters have left the current. Initially circle 2 drifters over the slope (with $K_{X} \propto l^{2.2}$ ) are more dispersive than the shelf and deep groups.

\section{Flux at the shelf break}

Fluxes are summarised in Table 4. Drifters crossing the isobaths during winter over the Hebrides slope provide an estimate of a mean isobath crossing speed of $0.02 \pm 0.01 \mathrm{~m} \mathrm{~s}^{-1}$ across the slope, decreasing at the shelf break to $4 \times 10^{-3} \mathrm{~m} \mathrm{~s}^{-1}$, both onto the shelf. Poleward $(Y)$ along-slope momentum is carried upslope, in the $X$ direction. The mean values, $\langle u v\rangle$, are estimated to be $2 \times 10^{-3} \mathrm{~m}^{2} \mathrm{~s}^{-2}$ at the $1000 \mathrm{~m}$ contour and $8 \times 10^{-3} \mathrm{~m}^{2} \mathrm{~s}^{-2}$ at the $500 \mathrm{~m}$ contour, but are not distinguishable from zero at the shelf break. This represents an accumulation along-slope momentum with along-slope distance and is consistent with the increasing slope current speeds.

A mass flux of similar scale is observed at the Shetland slope. Across the slope there is a shelfward mass flux velocity of $0.01 \mathrm{~m} \mathrm{~s}^{-1}$, and a polewardmomentum flux divergence at the upper slope, of $4 \times 10^{-3} \mathrm{~m}^{2} \mathrm{~s}^{-2}$ oceanward over the $500 \mathrm{~m}$ contour and shelfward at the shelf break. The net mass increase over the Hebrides and Shetland shelves is offset by an offshelf mass flux into the Norwegian Trench carrying with it a poleward (here southward) momentum flux, $\langle u v\rangle$, of $3 \times 10^{-3} \mathrm{~m}^{2} \mathrm{~s}^{-2}$.

Fluxes onto the shelf can be transitory whilst remaining important for chemical fluxes, e.g. because when slope water exists over the shelf, nitrogen is lost and carbon is gained. The time spent by drifters over the slope declined exponentially with an e-folding period of 5.5 days, and onshelf movement is principally limited to $20 \mathrm{~km}$, although transitory onshelf movement can last for 80 days, and travel $100 \mathrm{~km}$ onto the shelf.

During the summer the across-slope fluxes occur over the Hebrides slope at a similar rate to those observed during winter. There is an up-slope mass flux of 0.023 $\mathrm{m} \mathrm{s}^{-1}$ across the $500 \mathrm{~m}$ contour declining to $2 \times 10^{-3}$ $\mathrm{m} \mathrm{s}^{-1}$ across the shelf break. Along-slope momentum fluxes, $\langle u v\rangle$, are consistent at the $1000 \mathrm{~m}$ and $500 \mathrm{~m}$ contour, at $4.5 \times 10^{-3} \mathrm{~m}^{2} \mathrm{~s}^{-2}$, and marginally off-shelf at the shelf break, at $-7 \times 10^{-4} \mathrm{~m}^{2} \mathrm{~s}^{-2}$. Again the mass and momentum gains between the $200 \mathrm{~m}$ and $500 \mathrm{~m}$ are consistent and imply an overall gain in along-slope current velocity and transport at the Hebrides slope. Temporary fluxes onto the shelf are less important during summer. Of six such movements across the shelf break four last for fewer than five days and all stay within the outer $10 \mathrm{~km}$ of the shelf.

Table 4. Mean mass flux velocities, and momentum flux $\langle u v\rangle$ calculated for all drifters crossing the specified shelf edge and slope contours. The number of degrees of freedom in each estimate is given

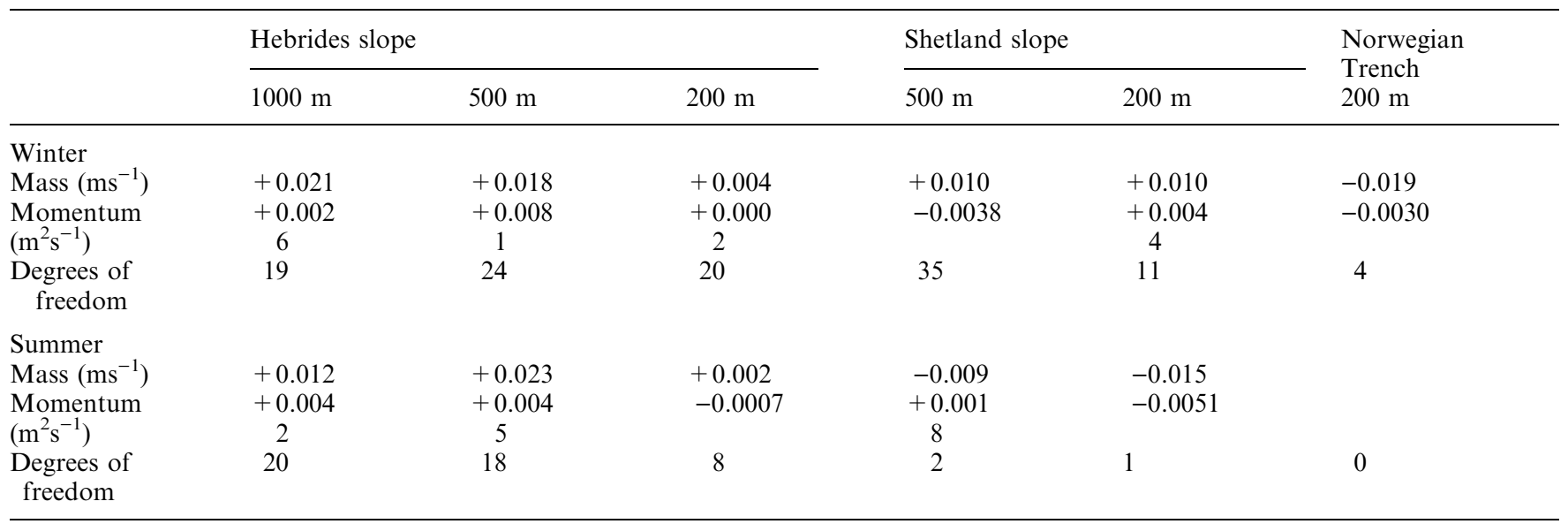




\section{Discussion}

The preceeding sections describe the tracks of two sets of drifters released on the continental slope west of Scotland. Perhaps the most striking result is the sensitivity of the drifter tracks to their release position during the first 100 days after release. Persistent eddies characterise the flows in the deep water of the Rockall Channel, in contrast with the irregular, sometimes slow, flows observed on the continental shelf. Flow in all areas is affected by strong winds, especially when stratification is weak in winter. The most pronounced currents are those flowing polewards along the continental slope. These are particularly affected by topography. Some of the features of the observed flow (e.g. the bifurcation and separation of the slope current near $57^{\circ} 20^{\prime} \mathrm{N}$, see Figs. 3a, 4a) would be difficult to establish by other means. Seasonal differences in flow and dispersion are evident in the general pattern of circulation (see Sect. 3, 6 and 7) and in that of more local regions (Sect. 4), for example the Fair Isle and East Shetland Current which provide vertically mixed oceanic and shelf water to the North Sea during late summer and autumn to drive a cyclonic density current around the Fladden Ground (Fig. 7). Turrell (1992) has identified the Fair Isle water as mixed North Atlantic and shelf water. The drifters indicate that the Shetland Shelf water originates from overflows at the Hebrides Shelf. The Fair Isle Current appears to be initiated during southwesterly gale force winds causing flow across the Orkney Shetland Ridge mixing front (Sect. 4). The East Shetland Current water is drawn from the same source as Fair Isle Current water and becomes vertically mixed to the north of Shetland. The current does not appear to be wind-initiated. Turrell (1992) suggests that both of these currents drive the cyclonic circulation. The few drifters entering the North Sea via the Fair Isle Channel during winter, the green track in Fig. 9 north of the Fladden Ground, do not circulate cyclonically around the Ground, but follow a convoluted path across the North Sea toward the Skagerrat.

Unexpectedly, the 100 day dispersion coefficients characterising winter and summer conditions do not differ significantly (Tables 1, 2 and 3). Nevertheless, Fig. 3 (winter) and Fig. 4 (summer) do show large differences, especially in the strength of the slope current and hence the greater transport in winter, and in the persistence of eddies in the Rockall Channel in summer. It is evident that the pattern of water movement, and more particularly dispersion, are undersampled even by the 21 drifters that were released on each occasion (e.g. only some 20 observations of movement from deep to shelf water were made; the statistical confidence in estimates is poor). The drifters have provided useful information about the importance of meteorological forcing and the effects of topography which will be helpful in guiding numerical models. Future investigation using drifters better equipped to sample the water properties and drogued at different levels would provide a rich source of further information in this complex area of interaction and exchange between the waters of the shelf waters and the deep ocean.

Acknowledgements. Dr D. Meldrum at the Dunstaffnage Marine Laboratory, Oban, Scotland, was responsible for the construction and deployment of the drifters. We gratefully acknowledge the help provided by the Officers and Crew of R.V Challenger and R.V Darwin for during the deployment cruises. This work is part of the Land Ocean Interaction Study (LOIS) Shelf Edge Study (SES), a Natural Environmental Research Council programme funded under grant code GST/02/0728. The drifter tracks are available from the British Oceanographic Data Centre in Bidston, UK.

Topical Editor D. Y. Webb thanks J. M. Huthnance and J. Simpson for their help in evaluating this paper.

\section{References}

Booth, D., Horizontal dispersion in the northeast Atlantic. DeepSea Res. 35, 1937-1951, 1988a.

Booth, D., Eddies in the Rockall Trough. Oceano. Acta., 11, $213-$ 267, 1988b.

Booth, D. A. and D. J. Ellett, The Scottish continental slope current. Cont. Shelf Res., 2, 127-146, 1983.

Burrows, M., S. A. Thorpe and D. T. Meldrum, Dispersion over the Hebridean and Shetland shelves and slopes, Cont. Shelf Res., In press, 1998.

Carter D. J. T, J. Loynes, and P. G. Challenor, Estimation of extreme current speeds over the continental slope of Scotland. Inst. Oceanogr. Sci. Rep., 239, pp 143, 1987.

Chereskin, T. K., P. P. Niller and P. M. Poulain, A numerical study of upper-ocean shear on flexible drogued drifters. J. Atmos. Ocean. Tech., 6(2), 243-253, 1989.

Davis D., Drifter observations of coastal currents during CODE: the statistical and dynamical views, J. Geophys. Res., 90, (C3), 4756-4772, 1985.

Ellett, D. J., A. Edwards and R. Bowers, The hydrography of the Rockall Channel - an overview, Proc. R. Soc. Edin., 88B, 61-8, 1986.

Garvine. R. W., K. -C. Wong and G. G. Gawarkiewicz, Quantitative properties of shelf break eddies J. Geophys. Res., 94, (C10), 14 475-14 483, 1989.

Hill A. E., Seasonal gyres in shelf seas, Ann. Geophysicae, 11, 11301137, 1993.

Hill A. E., R. Durazo and D. A. Smeed, Observations of a cyclonic gyre in the western Irish Sea, Cont. Shelf Res., 14, 479-490, 1992.

Huthnance, J. M., The Rockall slope current and shelf-edge processes, Proc. R. Soc. Edin., 88B, 83-101, 1986.

Huthnance, J. M., Circulation, exchange and water masses at the ocean margin: the role of physical processes at the shelf edge, Progress Oceanogr., 35, 353-431, 1995.

Krauss, W., The North Atlantic Current, J. Geophys. Res., 91, (C4), 5061-5074, 1986.

Krogh, F. T., Efficient algorithms for polynomial interpolation and numerical differentiation, Math. Comp., 24, 185-190, 1970.

Niiler, P. P., A. S. Sybrandy, K. Bi, P. M. Poulain and D. Bitterman, Measurement of the water following capabilities of holey-sock and TRISTAR drifters, Deep-Sea Res., 42, 19511964, 1995.

Okubo A., Oceanic diffusion diagrams, Deep-Sea Res., 18, 789-802, 1971.

Pingree R. D., Flow of surface waters to the west of the British Isles and in the Bay of Biscay, Deep-Sea Res. II., 40, 369-388, 1993.

Pingree R. D. and G. K. Mardell, Slope turbulence, internal waves and phytoplankton growth at the Celtic sea shelf-break, Philos Trans. R. Soc. London A, 302, 663-862, 1981.

Pingree R. D. and B. Le Cann, Celtic and Amorican slope and shelf residual currents, Prog. Oceanogr., 23, 303-338, 1989. 
Roberts. D. G., P. M. Hunter and A. S. Laughton, Bathymetry of the northeast Atlantic sheet 2. Continental margin around the British Isles, IOS, NERC, UK, 1977.

Simpson, J. F. and A. E. Hill, The Scottish slope current. The role of freshwater outflow in coastal marine ecosystems NATO ASI Series. G7, 295-308, 1986.

Svendsen E., R. Seatre and M. Mork, Features of the northern North Sea circulation Cont. Shelf Res., 11, 493-508, 1991.
Sybrandy, A. L. and P. P. Niiler, The WOCE/TOGA SVP Lagrangian Drifter Construction Manual, SIO Ref 91/6, WOCE Report 63, University of California, 58 pp., 1991.

Turrell, W. R., New hypotheses concerning the circulation of the northern North Sea and its relation to North Sea fish stock recruitment J. Mar. Sci., 49, 107-123, 1992.

Turrell, W. R. and E. W. Henderson, Transport events within the Fair Isle current during the Autumn Circulation Experiment (ACE). Est. Coast. Shelf Sci., 31, 25-44, 1990. 